\title{
Role of omics techniques in the toxicity testing of nanoparticles
}

\author{
Eleonore Fröhlich
}

\begin{abstract}
Nanotechnology is regarded as a key technology of the twenty-first century. Despite the many advantages of nanotechnology it is also known that engineered nanoparticles (NPs) may cause adverse health effects in humans. Reports on toxic effects of NPs relay mainly on conventional (phenotypic) testing but studies of changes in epigenome, transcriptome, proteome, and metabolome induced by NPs have also been performed. NPs most relevant for human exposure in consumer, health and food products are metal, metal oxide and carbon-based NPs. They were also studied quite frequently with omics technologies and an overview of the study results can serve to answer the question if screening for established targets of nanotoxicity (e.g. cell death, proliferation, oxidative stress, and inflammation) is sufficient or if omics techniques are needed to reveal new targets. Regulated pathways identified by omics techniques were confirmed by phenotypic assays performed in the same study and comparison of particle types and cells by the same group indicated a more cell/organ-specific than particle specific regulation pattern. Between different studies moderate overlap of the regulated pathways was observed and cell-specific regulation is less obvious. The lack of standardization in particle exposure, in omics technologies, difficulties to translate mechanistic data to phenotypes and comparison with human in vivo data currently limit the use of these technologies in the prediction of toxic effects by NPS.
\end{abstract}

Keywords: Cytotoxicity, Nanoparticles, Omics technologies, Transcriptomics, Proteomics

\section{Background}

Many scientists view nanotechnology as the revolutionary technology of the twenty-first century because it opened new possibilities for improvement of products used in healthcare, cosmetics, and medicine. Nanosized materials, on the other hand, can also have negative effects on human health, particularly when inhaled. Epidemiological data showed adverse action of air-borne ultrafine particles on humans, which were confirmed in animal exposures [1]. Toxicity of metal, metal oxide and carbon-based nanoparticles (NPs) is most relevant for human health because exposure to this group of NPs is highest, occurs over long periods and degradation and excretion of the ingested particles are low [2]. Numerous studies have addressed adverse effects of NPs exposure by in vitro and in vivo experiments. The vast majority

*Correspondence: eleonore.froehlich@medunigraz.at Center for Medical Research, Medical University of Graz, Stiftingtalstr. 24, 8010 Graz, Austria of in vitro studies used cell-based assays with phenotypic readout parameters, mainly membrane integrity, apoptosis, cell morphology, and proliferation. Oxidative stress was identified as mechanism of toxic action and, therefore, included in the routine testing. Toxicity testing of NPs in vivo comprised exposure of rodents and histopathological evaluation of liver, lung, spleen, kidney, brain, gastrointestinal tract, analysis of bronchoalveolar lavage fluid, blood count and clinical chemistry as readout parameters.

In the last years, principles, methodology and techniques of toxicity testing changed and these developments have also influenced the testing of NPs. One important change was the introduction of quantitative analysis of molecular and functional changes in multiple levels of biological organization in traditional toxicology testing (Fig. 1). The new strategy, termed systems toxicology, changed the current approach of relying almost exclusively on high-dose phenotypic responses in animals [3]. Core technologies in systems toxicology are the 


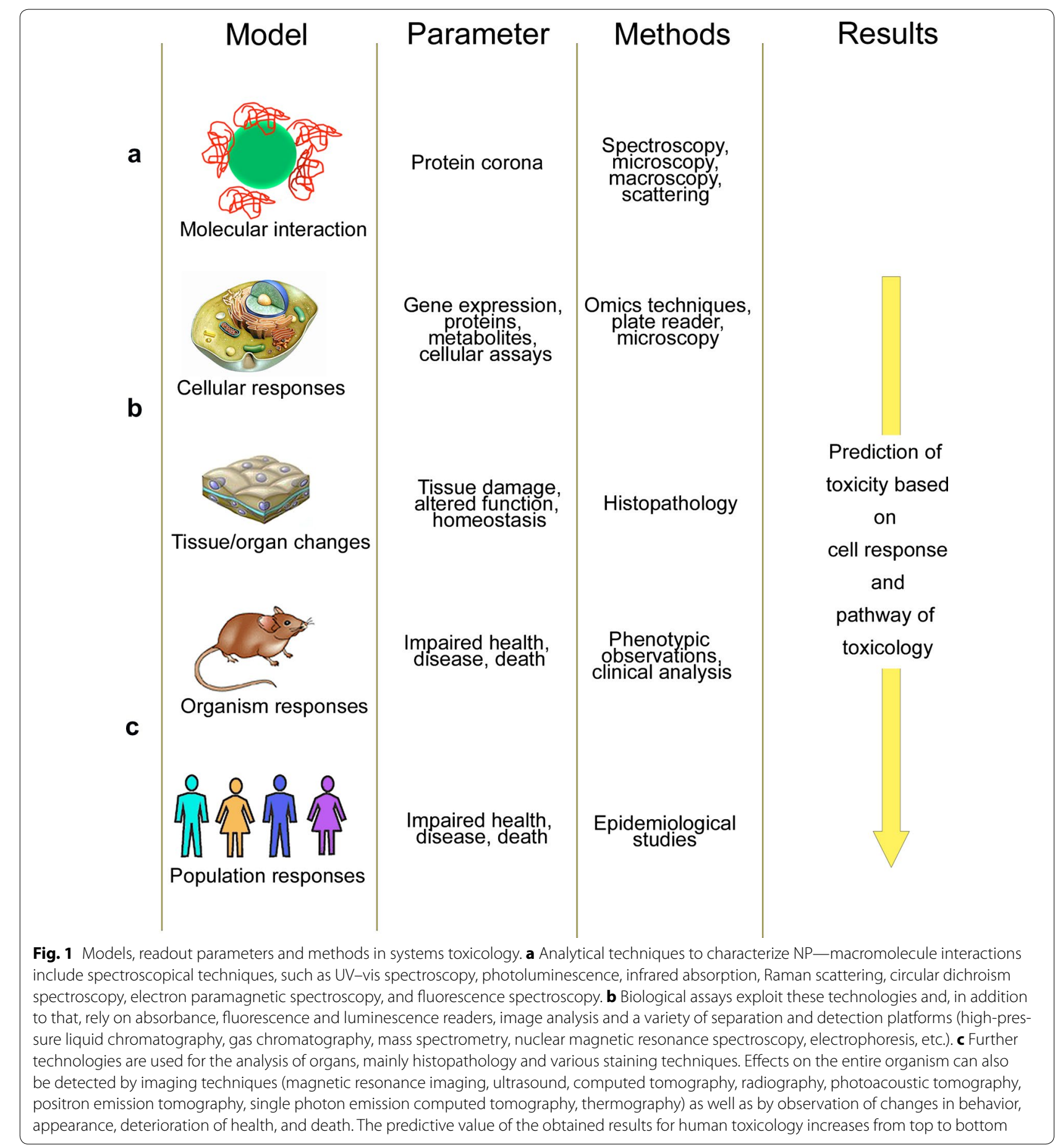

"omics" techniques, namely genomics, transcriptomics, proteomics and metabolomics. Omics technologies have also been used for in vitro and in vivo testing of NPs. One advantage might be the identification of new targets and markers for NP toxicity. Such markers would be very useful because exposure to NPs occurs at low levels. If realistic exposure levels are used in conventional in vitro testing it is possible that no phenotypic changes occur because exposure duration is too short. The application of higher doses, on the other hand, may lead to a different cell response because particle agglomeration and stability of the dispersion depend on the particle density [4]. By the use of transcriptomics, however, adverse effects of low particle concentrations on cells may be detected 
because the techniques identify changes before phenotypic changes are obvious. Another advantage of the omics techniques would be their lower interference with NPs. False positive and negative results in conventional screening assays have been frequently described. They are due to interference by color, fluorescence, chemical activity, light scattering, etc. (e.g. [5]). In contrast, similar problems have not been reported in omics studies. Removal of the NPs during the isolation procedure of the analyte appears to be the most likely reason for that. The use of omics techniques, however, requires more expensive infrastructure and skilled personal in sample preparation and data analysis than conventional testing. Based on the overview of NP studies using omics techniques in vitro and in vivo, this review aims to answer the following questions (i) are omics technologies able to identify new targets in nanotoxicology, (ii) are the technologies robust enough to be used for toxicity screening, (iii) to which extent do the reported regulations correspond to results obtained in phenotypic assays.

NPs contained in commercial products with relevance for human exposure were addressed in this review. They appear suitable for such a comparison although the action of some of the NPs is caused partly by dissolved ions. The different omics technologies are shortly introduced and data within the same study, between platforms and between research groups and NP action across the platforms and phenotypic assays compared. Finally, a comparison of omics technologies to high-throughput phenotypic testing is made.

\section{Omics techniques}

The suffix "omics" stands for "as a whole" and includes epigenomics, genomics, transcriptomics, proteomics and metabolomics. These studies differ from the traditional observation of phenotypes in the way that they can provide primarily mechanistic information and may identify the pathway of toxicity. Based on these techniques it is possible to identify adaptive responses to toxicants at low levels that do not yet cause toxicity but put cells or organisms under stress, which reflects the situation of particle exposure. Identification of cellular stress is important because manifest toxicity occurs when the compensation system is exhausted. An example for the manifestation of adverse effects only upon challenge of the organism is the decreased antibacterial defense of mice that have been exposed to CoO NPs [6].

Toxicants that do not interact or bind to a single type of macromolecule can perturbate multiple pathways and result in a broad activation of pathways. NPs influence various cellular processes (proliferation, apoptosis, inflammation, membrane integrity) [7] and induce such a pattern. In this case, it is usually difficult to deduce the pathway of toxicity from the regulation pattern [3].

Systems toxicology includes genomics, epigenomics (miRNomics and DNA modifications), transcriptomics, proteomics, and metabolomics. Genomics investigates genes and their functions by use of recombinant DNA, DNA sequencing and bioinformatics to analyze function and structure of the genome. The goal is to identify a particular sensitivity of individuals to a given toxin rather than the screening for toxicity of compounds or NPs. The epigenome can be altered by toxicants and, therefore, is useful for toxicity screening.

A detailed description of the respective detection techniques is out of the scope of this review and only the basic principles of the respective techniques will be mentioned.

\section{Epigenomics-miRNomics}

Regulation by miRNAs belongs to the group of epigenetic effects, which are heritable changes in phenotype or gene expression not caused by changes in DNA sequence. MiRNAs are a class of small endogenous noncoding RNAs that, typically, down-regulate gene expression either by interfering with protein synthesis via base pairing (complementary sequences with mRNAs) or by targeting RNA degradation. MiRNAs are produced as primary mRNAs and, still in the nucleus, are processed to pre-mRNAs with stem loop structure. After transfer to the cytoplasm the pre-form matures to RNA duplexes, which release a guide and a passage strand. Only the guide or dominant strand is incorporated in the RNAinduced silencing complex (RISC). The opposite strand (passage or star strand) is quickly degraded. MiRNomics is a relatively new screening platform [8]. MiRNAs are early indicators of cell damage and can be detected in peripheral blood due to slow turnover of the dominant strand. With only around 2000 miRNAs miRNomics might be a better platform for toxicity studies than whole genome expression analysis. The technology is used to identify drug-induced hepatotoxicity, cardiotoxicity, and nephrotoxicity. qPCR profiling of miRNA also identified systemic effects after inhalation of diesel exhaust particles. According to the miRNA profile inhaled PM2.5 induced oxidative stress in asthmatic patients [9]. The physiological relevance of this finding, however, is not yet clear because no correlation of miRNA regulation with airway hyper-responsiveness was seen. The lack of correlation to in vivo findings is one reason why miRNomics is not yet widely used in toxicity screening also of conventional compounds. Toxicologists currently do not completely understand the contribution of miRNA in regulating toxicological outcomes [10]. 
Epigenomics-DNA methylation and histone modification The epigenome further includes DNA methylation, posttranslational modification of histone tails, and chromatin remodeling. DNA methylation is the main mechanism for the down-regulation of gene transcription by preventing the transcription machinery to bind. Its main importance is seen in tumor biology because DNA hypomethylation in tumors is linked to progression and malignancy [11]. Histones are basic proteins that organize eukaryotic DNA into structural units. Binding of histones to DNA is accompanied by decrease of transcription and can be regulated by a variety of post-translational modifications [12]. Histones in the modified state detach from the DNA and, thereby, activate transcription. Increased activity of enzymes that remove these modifications, mainly histone deacetylases, are involved in cancer progression [13]. Epigenetic changes are involved in the transformation and mutation of cells and, therefore, may serve as indicator for genotoxicity. The biological relevance of an altered epigenome is not yet clear because DNA hypomethylation may cause cancer but may also be a consequence of the transformed state induced by altered cell signaling pathways [14]. Therefore, epigenetics is also not (yet) a part of routine pre-clinical evaluation of drugs. Epigenomic studies use a variety of technologies. Histone acetylation is determined mainly based on antibody binding using immunohistochemistry and Western blot. DNA methylation can be quantified by polymerase chain reaction, pyrosequencing, high performance liquid chromatography (HPLC), enzyme-linked immunosorbant assay (ELISA), etc. [15].

Pathways that may indicate adverse effects on DNA are regulation of DNA damage and repair and of nucleic acid metabolism (listed in Table 1).

\section{Transcriptomics}

The transcriptome represents the entire set of transcripts or mRNAs present in a cell or an organism and is studied by a panel of molecular biological techniques. Gene expression profiling determines the expression level of all mRNAs at a given time point by DNA microarray, next generation RNA sequencing, subtraction hybridization, differential display, or serial analysis of gene expression. Current estimations indicate a number of around 19,000 coded genes [16], which are represented in commercially available whole genome expression arrays. cDNA microarray analysis is the most established omics technique and the testing should ideally be performed across both dose and time. Extracted RNA is subjected to reverse transcription to obtain labeled cDNA or to RNA polymerase amplification to generate labeled cRNA. The sequences are hybridized to oligonucleotides on microarrays and scanned under laser light. After analysis of the hybridization, the identified genes are allocated to pathways based on databases. The advantage of transcriptomics is that only one type of biomolecule has to be extracted and analyzed, compared for instance to proteomics, where different protocols have to be used. A known limitation of transcriptomics is the fact that changes in mRNA expression do not influence the phenotype directly. Transcriptomics is a very established technique with high intra-array reproducibility. Comparison between array platforms, on the other hand, varied with a Pearson correlation coefficient of 0.5-0.95 [17]. Problems include inaccuracy for genes with low expression levels and the fact that not all probes on the arrays match the target genes to the same degree.

\section{Proteomics}

Proteomics describes the analysis of functionally, structurally and anatomically related proteins and can provide more direct information on cellular responses than gene regulation because protective cell responses are often orchestrated through fast modification or changes in cellular localization of proteins. Separation steps to deplete high abundance proteins and chromatographic enrichment help to detect specific proteins and are introduced to improve coverage, sensitivity, reproducibility and throughput of proteome-based analysis. By using two-dimensional electrophoresis around 10,000 distinct proteins can be separated [18]. Fluorescence-labeling or stable isotope-labeling can identify differences in treated versus untreated samples. Analysis can either be bottomup or top-down. In the first variant peptides released from proteins through proteolysis are analysed [19]. This technique has been termed shotgun proteomics and is widely used. In top-down proteomics intact proteins are analysed. Due to the worse fractionation, ionization and fragmentation in the gas phase, this technique is less universal than the bottom-up technique. Detection uses mainly mass spectrometry (MS) because the platform is relatively flexible and allows the detection of amino acids, peptides and proteins. The mass spectrometer consists of the ionizing source and one or more analyzers. Matrixassisted laser desorption ionization (MALDI) and electrospray ionization (ESI) are most commonly used for ionization of the molecules, which are then accelerated into time of flight (TOF), ion trap, quadrupole, orbitrap or Fourrier transform ion cyclotron resonance (FTIR) analyzer. Analyzers are usually used in tandem (MS/MS) to achieve higher degree of ion separation and identification. As for transcriptomics calibration and analysis based on proper databases is essential for data interpretation. Due to the detection technique, which includes digestion of the proteins, databases list between 15,000 and 42,000 proteins and between 100 and 2000 millions 


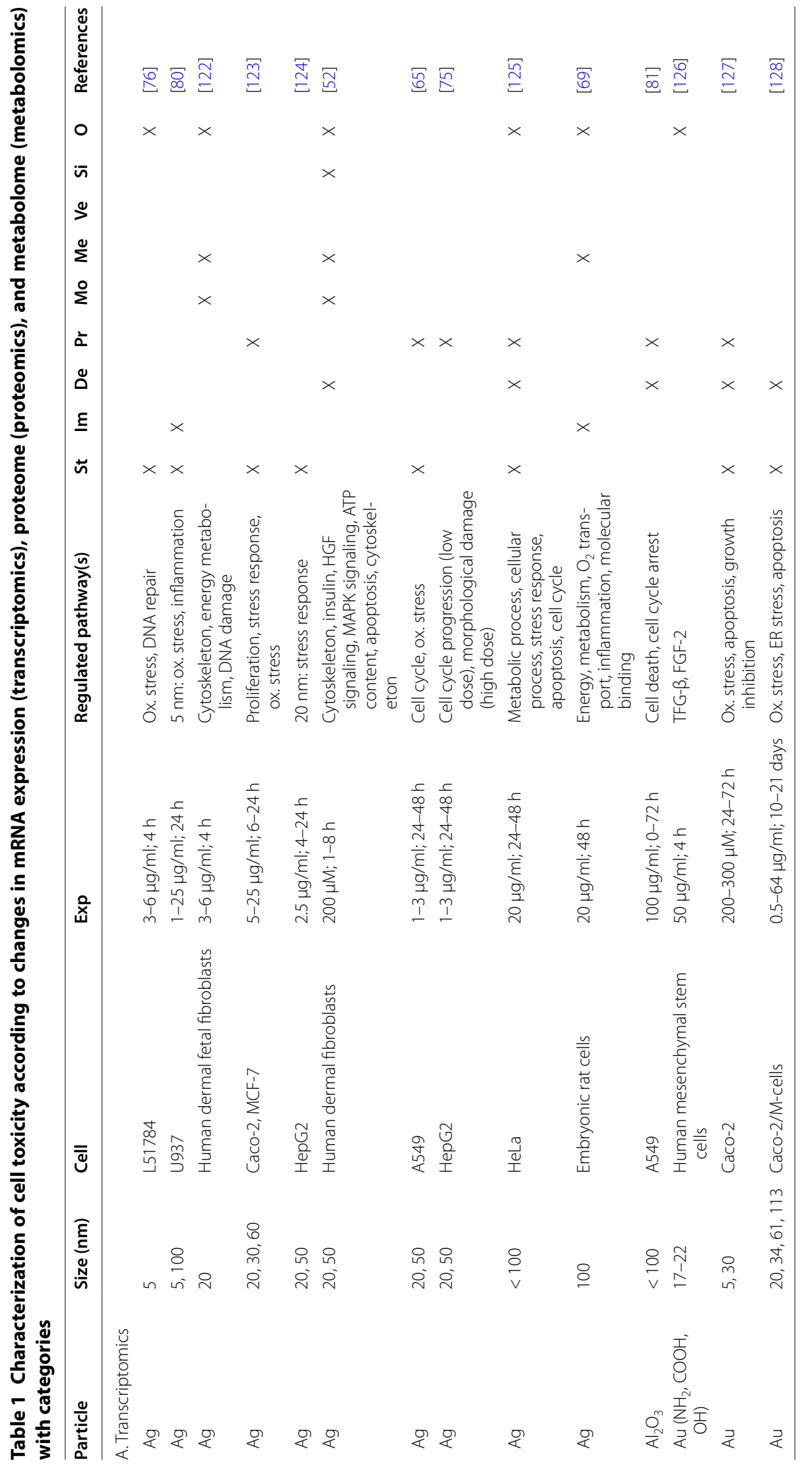




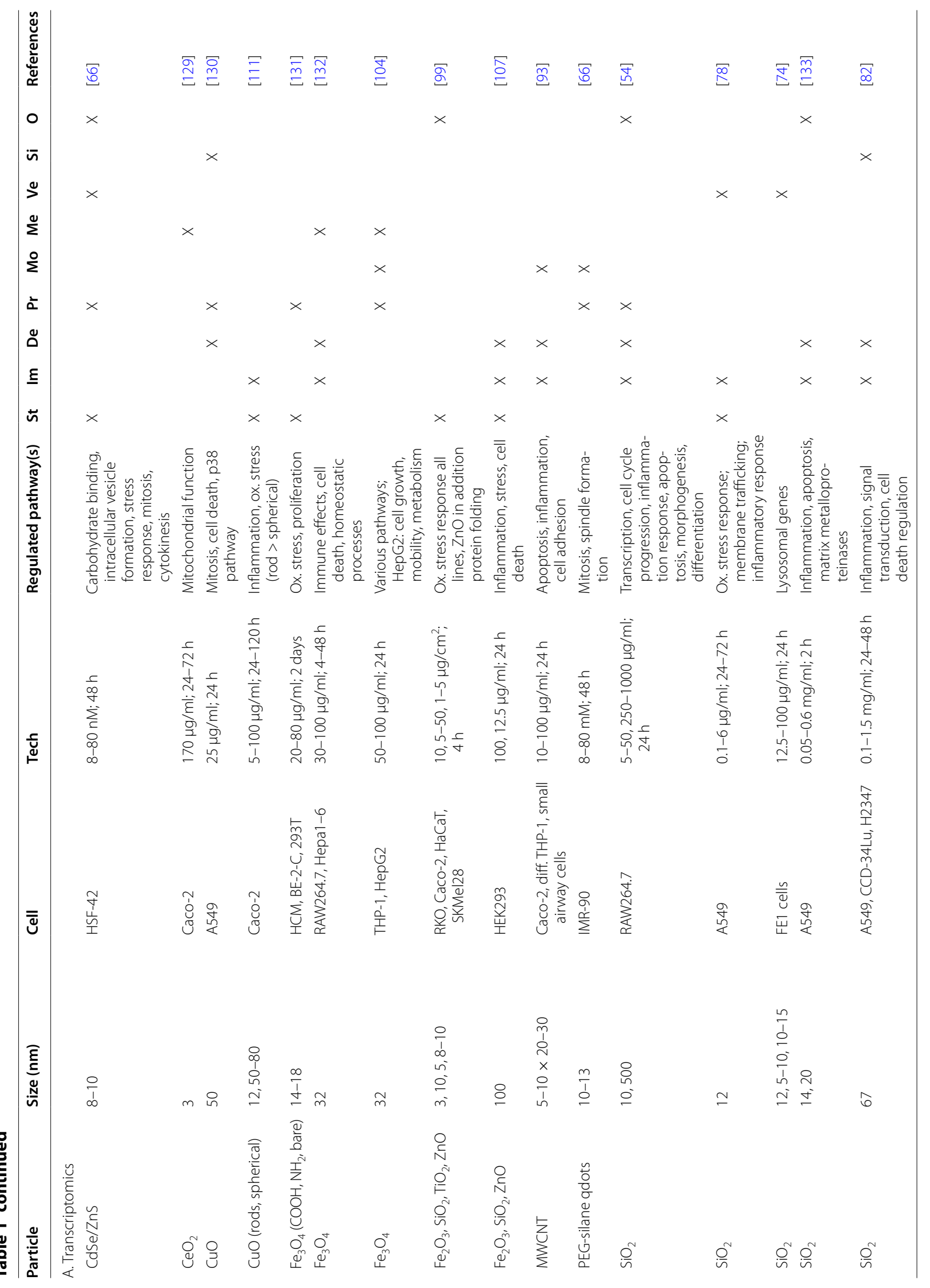




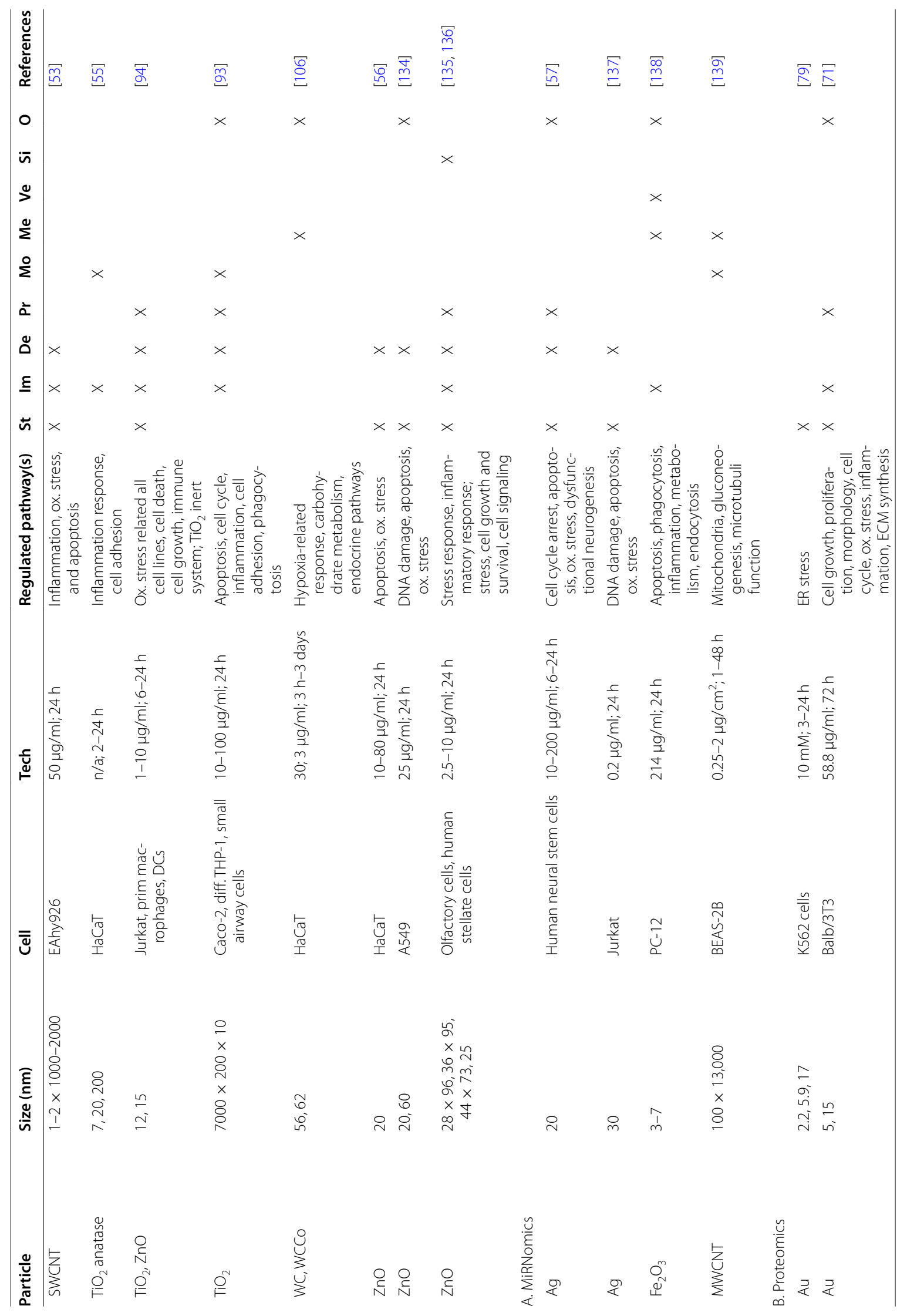


Fröhlich J Nanobiotechnol (2017) 15:84

Page 8 of 22

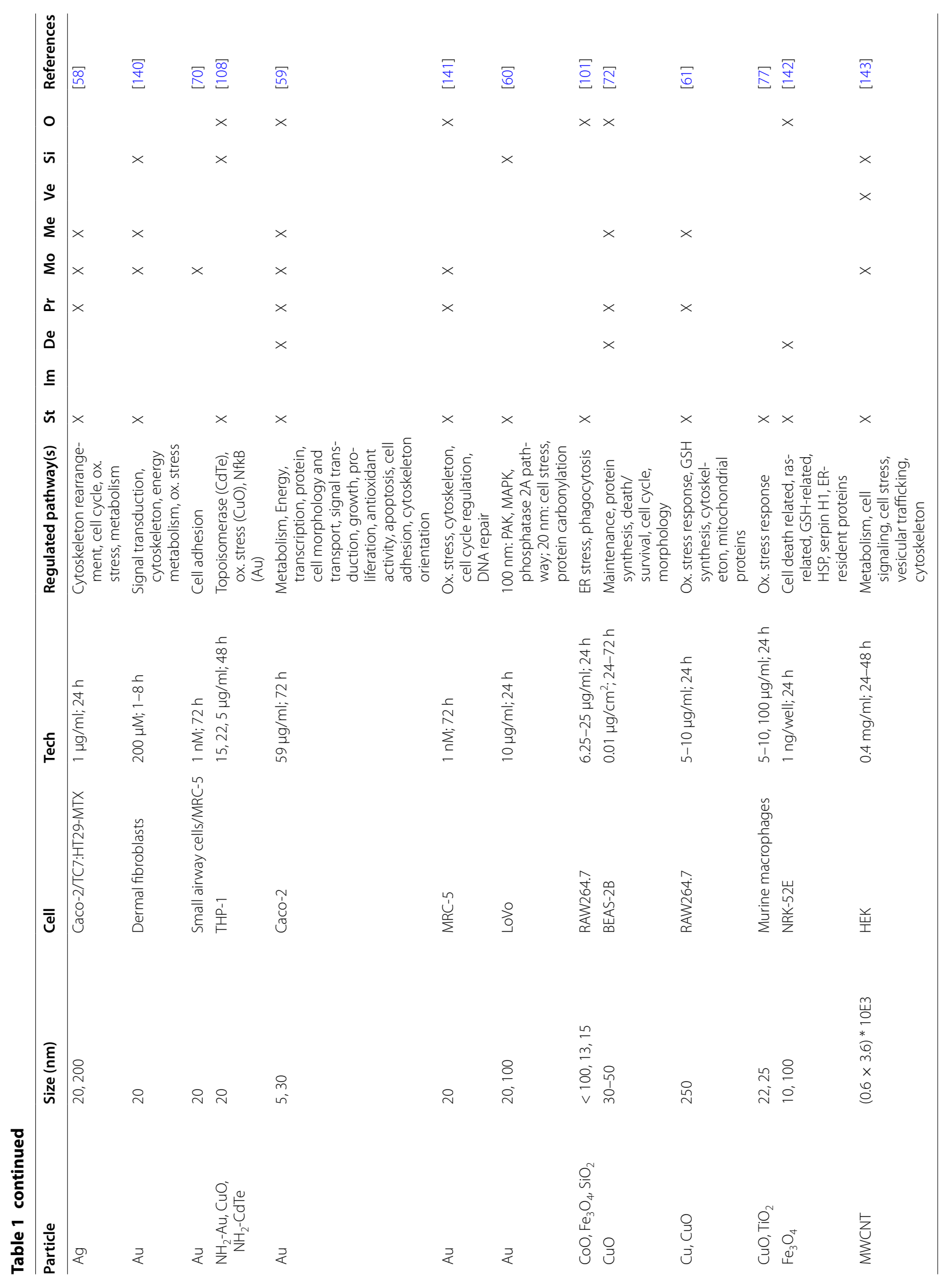




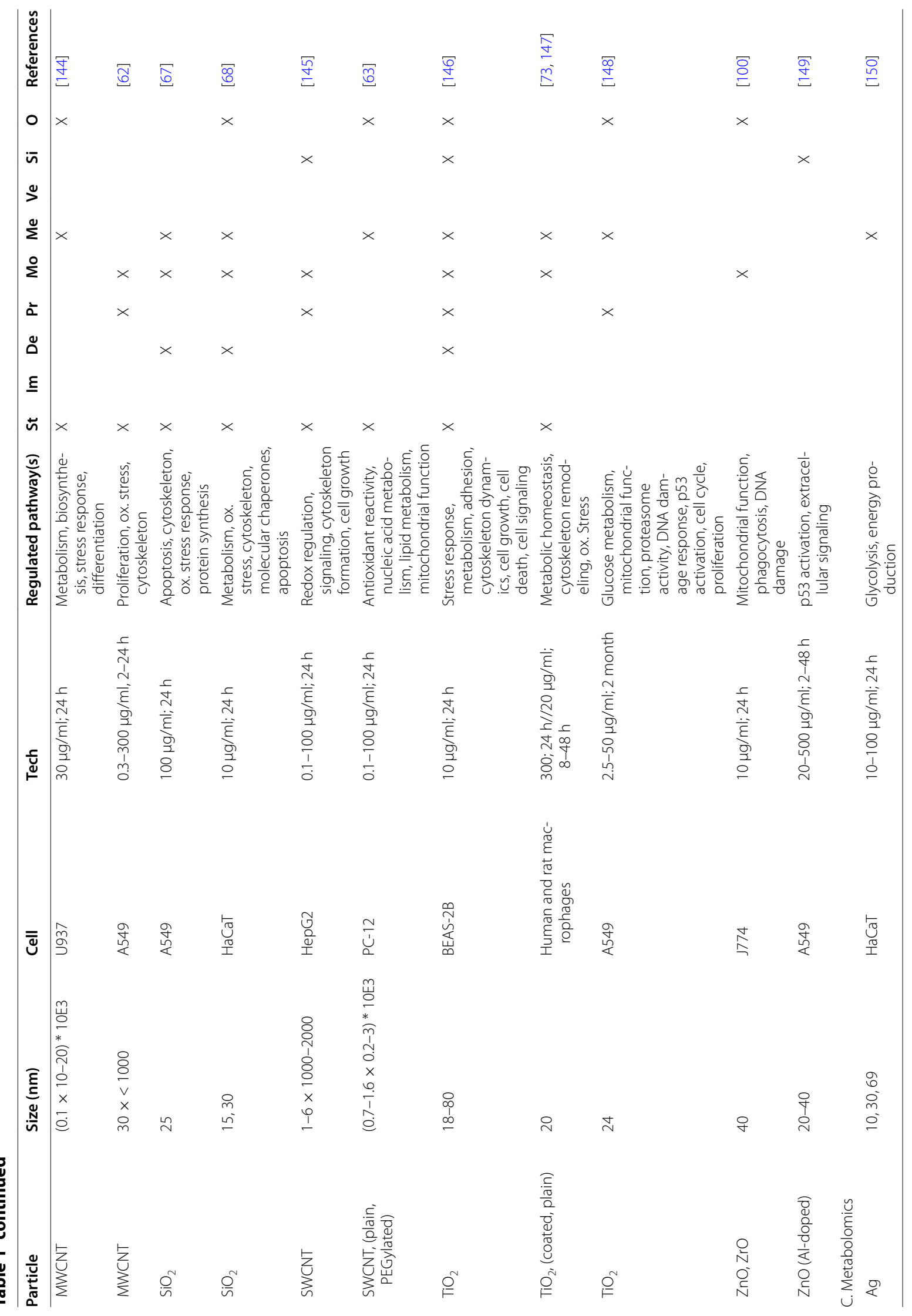




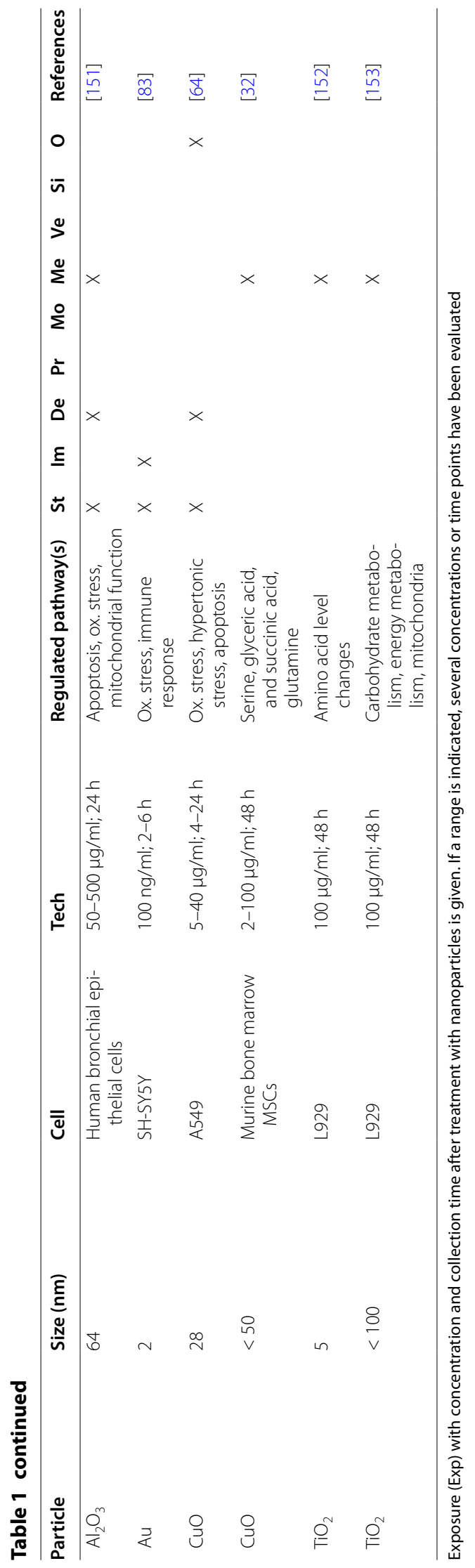


of peptides [20]. Limitations of proteomics are both biological and technical. The preparation is prone to contamination, and protein expression varies in response to circadian cycles, age, sex and disease. In addition to that, there are many proteins with partly unknown functions; the sensitivity of MS is still lower than other protein detection techniques (e.g. ELISA or Western blot), and usually only water-soluble proteins in a limited range of mass and isoelectric point are analyzed.

In addition to identification of regulated pathways, proteomics plays a specific role for particle characterization because it has been used to characterize proteins that are absorbed to the surface of NPs. The coverage of surfaces with macromolecules, predominantly proteins, is usually referred to as "protein corona" [21]. The binding of the macromolecules affects dispersion of particles in physiological fluids and consists of a relatively stable "hard" layer, which forms within seconds and a less stable "soft" layer that forms within minutes to hours [22]. The composition of the layer depends on absorption and desorption of macromolecules, where the velocity of desorption is the inverse of the velocity of absorption. The two corona layers appear to have different roles for the biological response. The hard layer is resistant and still present after cellular uptake by endosomes, while the soft layer is less stable and determines uptake and biological responses. Various groups studied the protein corona composition using proteomics. Influence of material, particle size and surface charge, hydrophobicity/hydrophilicity, incubation time and type of biological fluid has been reported [23-29]. The studies reported qualitative and quantitative differences in the composition of the protein corona but also a common set of bound proteins. Cytotoxicity of NPs possessing a protein corona was generally lower than toxic effects of NPs without. It is not clear whether a decreased interaction with plasma membrane and decreased production of reactive oxygen species or specific molecules within the layer cause this effect. A link of specific proteins within the protein corona to cytotoxicity has not been identified so far.

\section{Metabolomics}

Compared to the transcriptomics and proteomics, which provide information of potential hazards, metabolomics identifies phenotypic changes that occurred in the presence of the toxicant by measuring changes in carbohydrate, lipid, and amino acid patterns. Metabolomics differs from the former techniques in the way that it is not organism-specific and does not have a fixed code [30]. Metabolomics profiling assesses changes in the entire metabolome and is performed either as footprint (analysis of extracellular metabolites) or as fingerprint (analysis of the intracellular metabolites). To distinguish between these two profiles it is important to prevent leakage of metabolites from cells. Washing may not be ideal because it delays sample processing, which is crucial in order to prevent changes of the metabolite profile after the sampling. The basic workflow including separation and enrichment of the analyte proceeds in a similar way as for proteomics. While analysis by Nuclear Magnetic Resonance (NMR) can detect a variety of metabolites in relatively crude preparation with high reliability, the technique is relatively insensitive and only $<100$ metabolites can be detected. MS based techniques are usually preferred because of the higher sensitivity. Separation of the metabolites uses gas chromatography (GC) and liquid chromatography (LC). GC is the ideal method for volatile samples; non-volatile samples can be detected after derivatization. LC can easily separate non-polar metabolites, while polar metabolites may require derivatization. The identity of the metabolites is established by MS-MS fragmentation and comparison of the resulting fragmentation spectra to a reference database. Inter-experiment comparability needs "house-keeping" metabolites or isotope-labeled standards. The relative inexpensiveness of the analysis, the non-invasiveness of the sampling, the low number of metabolites and the good knowledge of the role of most metabolites in the organism make metabolomics particularly suitable for the study of toxicology [31]. There are several limitations to this technology too. The metabolites are not organism-specific and the concentration range can span at least six orders of magnitude. This range cannot be easily compensated because amplification of the signal is not possible. Furthermore, different detection techniques have to be used because metabolites belong to different classes of molecules [30]. Therefore, many studies do not analyze the entire metabolome but use metabolic target analysis or metabolomics profiling, where the analysis is restricted to metabolites of a specific pathway or to a specific group of molecules (for instances lipids). The number of metabolites which is usually detected ranges between 2000 and 7000 , although 42,000 metabolites have been entered in the Human Metabolome Databank. Metabolomics identified differences in cellular effects induced by NPs and by microparticles. In the free metabolite screening of human bone marrow mesenchymal stem cells treated with $\mathrm{CuO}$ particles the increase in glutamine could discriminate nano-from microparticles [32].

\section{Omics data in nanotoxicology}

Combinations of the keywords "nanoparticles", "silver, "gold", "silica", "titanium dioxide", "copper oxide", "zinc oxide", "carbon nanotubes", "toxicity", "nanotoxicity", "whole genome expression analysis", "epigenetics", "proteomics", "transcriptomics", "metabolomics", "miRNA 
Fröhlich J Nanobiotechnol (2017) 15:84

Page 12 of 22

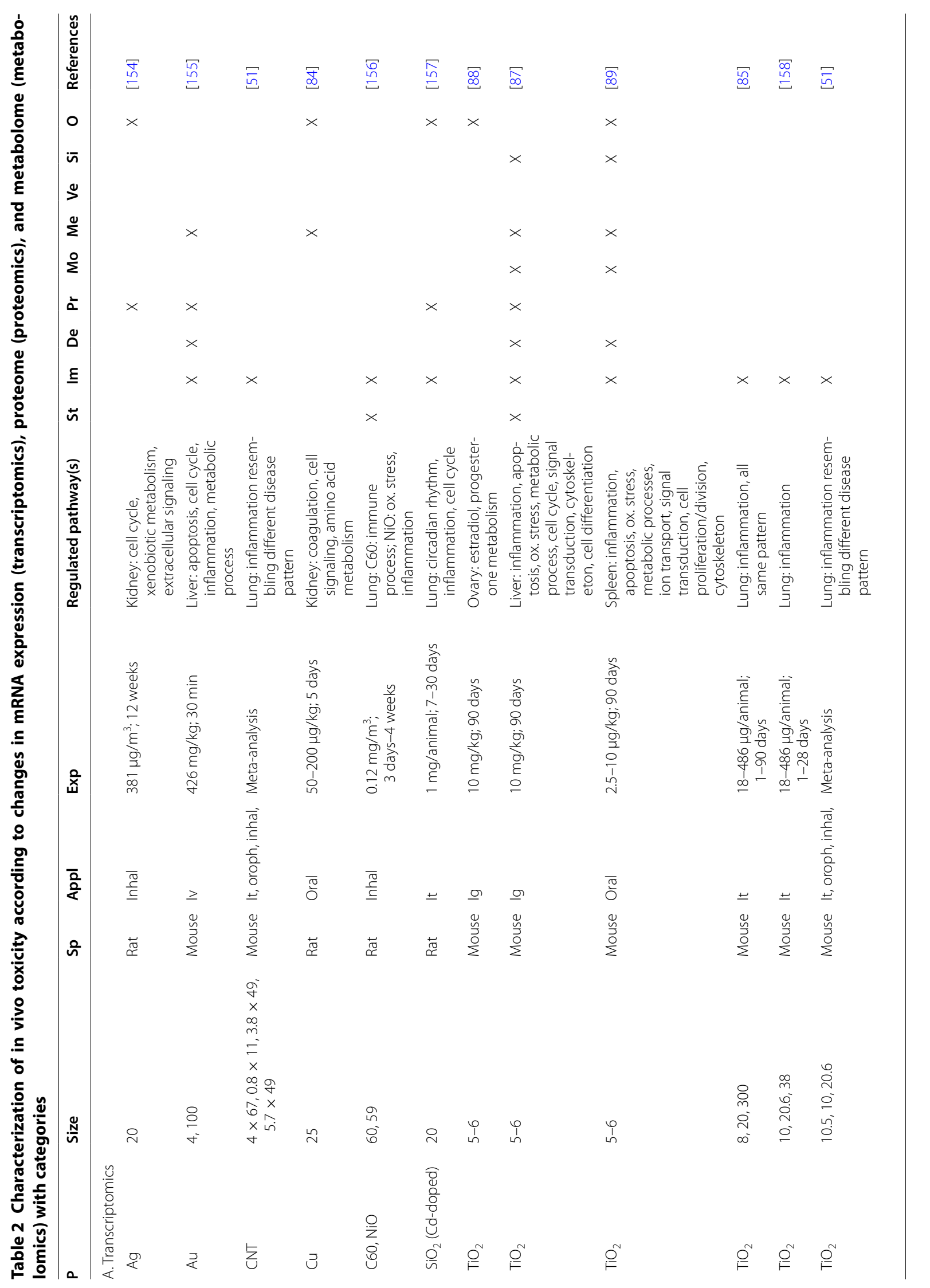




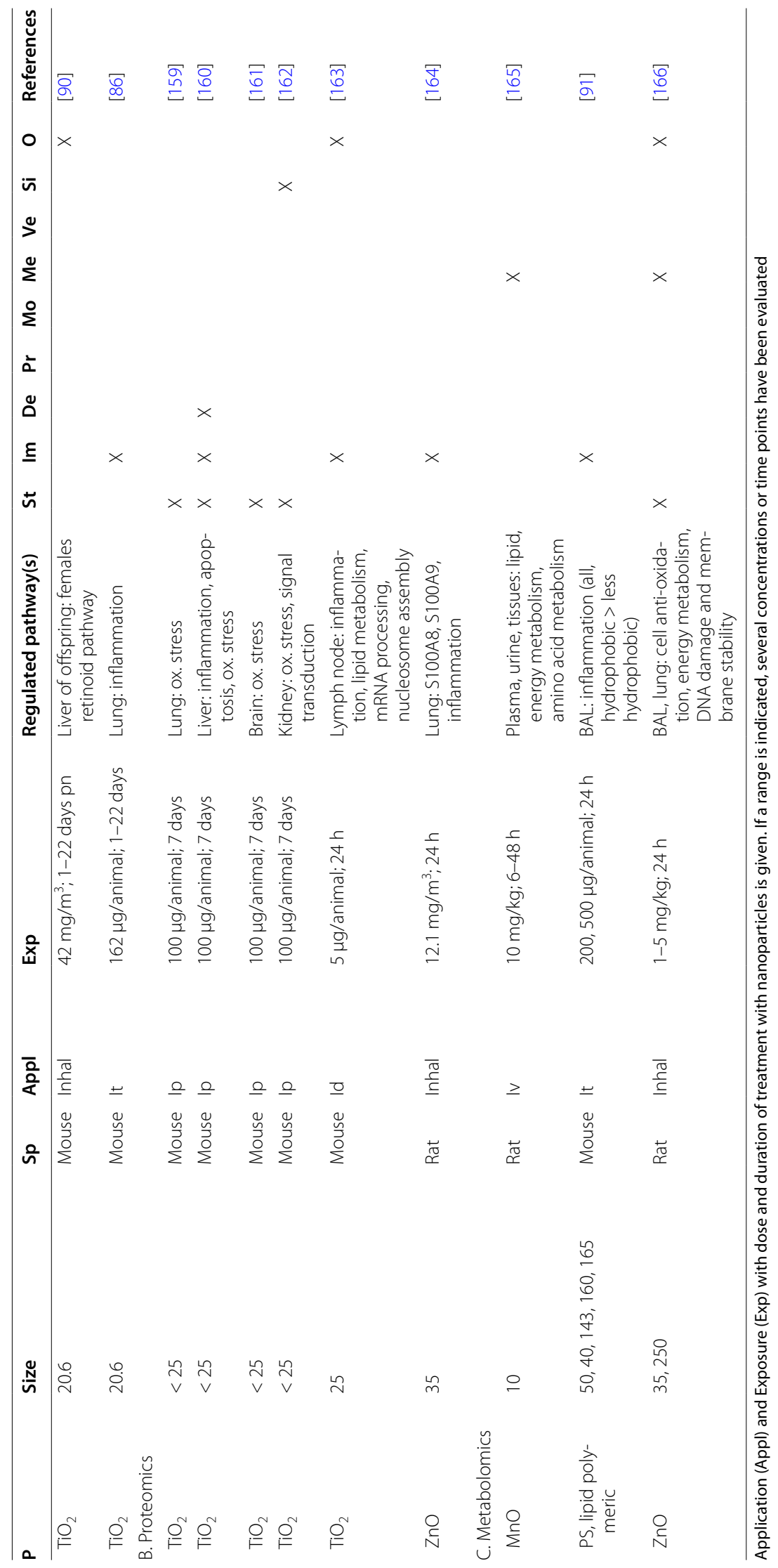


analysis", and "miRNomics" were used for searches in PubMed and other search machines. For the overview of the in vitro results, particle (material and surface functionalization), particle size, exposure dose and duration, cells used for the studies, and reported regulated pathways are summarized in Table 1 . Table 2 contains indication of particle (material and surface functionalization), particle size, animal species, exposure route, exposure dose and duration, and reported regulated pathways reported in animal studies.

In the vast majority of studies NPs had an effect on regulation of genes, proteins or metabolites and only few studies reported no effects of NPs. For instance, gold NPs had no significant effect on gene regulation of human vein endothelial cells [33] and no alterations of the protein expression profile was observed in adipose tissue derived stem cells after exposure to $900 \mathrm{~nm}$ superparamagnetic iron oxide particles [34].

As the reporting of regulated pathways/processes is not standardized, in order to compare regulated pathways between omics techniques and phenotypic assays the following groups have been formed. Stress: oxidative stress, stress response, antioxidant reactivity, GSH-related, HSP, ER stress, cell stress, chaperones; immune: inflammation, immune response, phagocytosis; death: apoptosis, cell death; proliferation: mitosis, growth, proliferation, differentiation, transcription; morphology: cytoskeleton, adhesion, mobility, cytoskeleton organization; metabolism: mitochondria, ATP content, homeostasis, gluconeogenesis, glycolysis, protein synthesis, amino acid levels, energy metabolism; vesicles: membrane trafficking, lysosomes, vesicles; signaling: cell signaling (mitogen-activated protein kinase (MAPK), p53, p38 MAPK), signal transduction, and genotoxicity: DNA damage, DNA repair, nucleic acid metabolism.

\section{Epigenomics}

DNA methylation and histone acetylation studies do not provide pathway regulation pattern as output and are, therefore, not included in Table 1. They can, however, be used in toxicological screening and data be linked to phenotypic data obtained by classic genotoxicity assays. DNA hypomethylation has been reported after cellular exposure to $\mathrm{SiO}_{2}, \mathrm{ZnO}, \mathrm{TiO}_{2}, \mathrm{CuO}$, and Ag NPs [35-38] but effects on global DNA methylation in vivo by $\mathrm{CuO}$ NPs, Au NPs and SWCNTs are modest [39, 40]. Promoter methylation is increased by $60 \mathrm{~nm}$ Au NPs and decreased by SWCNTs in blood cells after intratracheal application of the particles [40]. NPs modify histones by binding to $\mathrm{SH}$ groups of histone deacetylases, decreasing the enzymatic activity (Au NPs) [41], or inducing histone hypoacetylation in breast cancer cells (cadmium tellurite (CdTe) quantum dots) [42]. The available data suggest that exposure to NPs may favor cell transformation and tumor development. Conventional phenotypic genotoxicity assays for chromosome damage, for instance COMET assay or micronucleus assay, show variable and partially conflicting results. $\mathrm{TiO}_{2}$ particles in sizes $<100 \mathrm{~nm}$ showed positive results in COMET assay (17/24), micronucleus (12/16), and sister chromatid exchanges $(2 / 2)$ but predominantly negative results in COMET (3/5) and micronucleus (2/3) in vivo studies [43]. Also $\mathrm{ZnO} \mathrm{NPs}$ showed genotoxic action in cellular but not in in vivo studies [44], while studies of $\mathrm{SiO}_{2} \mathrm{NPs}$ reported weak genotoxic action in vitro and no genotoxicity in animal studies [44]. Lastly, $\mathrm{CuO}$ and Ag NPs showed genotoxicity in vitro [45-47] and in vivo [48, 49]. Variation in fibre length, contamination with heavy metals and pretreatment of the CNTs samples prevent inter-study comparison. It appears that long CNTs induce genotoxicity, while short CNTs do not induce prominent genotoxicity [50]. Phenotypic assays and epigenetic assays identified more damage in cellular than in animal studies. Pathway regulation of DNA damage and repair and nucleic acid metabolism as indication for genotoxicity was also more frequently reported in in vitro than in in vivo studies. The higher frequency of epigenetic changes than of genotoxic effects indicates that epigenomic changes induced by $\mathrm{SiO}_{2}$ and $\mathrm{TiO}_{2}$ NPs may not result in manifest chromosome damage because repair mechanisms could prevent it. It is, however, possible that the particles act as a challenge making cells more vulnerable to the action of other genotoxic agents.

\section{Particle effects according to transcriptomics, proteomics and metabolomics studies}

Reported regulated pathways were classified according to phenotype changes as routine parameters in toxicity testing. This has the limitation that information on the regulated genes, proteins or metabolites is lost and that high quality and low quality studies are treated equally. Studies using transcriptomics (50) and proteomics (33) were more numerous than studies reporting metabolomics (10) and miRNomics (4) data (Table 1). The number of reports on cellular transcriptomics (37), proteomics (27), metabolomics (7), and miRNomics (4) was higher than that of in vivo studies using these techniques (13 in transcriptomics, 6 in proteomics, and 3 in metabolomics, Table 2). One meta-analysis of gene regulation after pulmonary exposure to CNTs (3) and to $\mathrm{TiO}_{2} \mathrm{NPs}$ (2) was identified [51]. Transcriptomics studies focused on $\mathrm{Ag}, \mathrm{SiO}_{2}$, and $\mathrm{ZnO}$ NPs, while $\mathrm{Au}$ and CNTs were most intensely investigated by proteomics (Tables 1,2 ). Pathways were reported with different frequencies in the omics studies. Proliferation, oxidative stress, and immune pathways were mainly affected according to transcriptomics in cells 
(Table 1). Regulation of inflammation according to transcriptomics was also frequently reported in the in vivo studies of NP exposure by the pulmonary route (Table 2), while more variable regulation pattern were seen after oral and intravenous application. In miRNomics studies various pathway regulations have been reported but due to the low number of miRNomics studies a preference for specific regulation pattern would not be easy to discern. Proteomics of cells reported oxidative stress, morphology, energy metabolism, mitosis and apoptosis as most affected by NP exposure (Table 1). When particles were applied by pulmonary and dermal routes in animals regulation of inflammation was reported (Table 2). Metabolomic studies reported NP effects on oxidative stress, energy metabolism, apoptosis and other pathways in cell exposures (Table 1). In the in vivo studies effects on inflammation were identified (Table 2).

Several studies assessed NPs by omics techniques and phenotypic assays. Usually, only cytotoxicity screening assays was performed to determine the concentration range for the omics studies. This is important because strongly cytotoxic concentrations should be avoided as dead cells provide only limited information on regulatory mechanisms. If, on the other hand, concentrations far outside the toxic range are used, no changes in regulation will be seen. Effects at different particle concentrations were recorded in some studies because reaction to low and high particle concentrations may differ. Comparison with complementary techniques can confirm omics results and support relevance of the reported regulation pattern. Studies combined plate reader analysis of cytokine secretion, mitochodrial activity, cell death, and ROS generation [52-64], flow cytometry for cell cycle analysis and cell death [57, 65-68], microscopy for morphology and immunocytochemical staining [52, 57, 59, 67-73], and genotoxicity assays [74-77] with omics techniques. Other researchers used verification of the regulated pathways by using another omics technique [52, 78, 79]. Influencing the regulated pathway by addition of an antioxidant or studying cell recovery after removal of the particle challenge confirmed involvement of oxidative stress [80-83]. Histology [84-89], analysis of bronchoalveolar lavage fluid [85, $90,91]$ and clinical chemistry [84] were performed to support the results of the omics in vivo studies.

The majority of transcriptomic studies evaluated samples up to $24 \mathrm{~h}$, while proteomics studies mainly collected sample at $\geq 24 \mathrm{~h}$ (Table 1 ). mRNA is produced in oscillatory manner and the collection time of the sample is not representative for the levels before and after this time [92]. To avoid this bias, most transcriptomics studies analysed samples at different time points. The majority of proteomics and metabolomics studies, on the other hand, analysed only one time point.
The comparison with another omics technique showed that endoplasmatic reticulum stress induced by Au NPs could be demonstrated on genetic and protein level [78]. Regulated genes and proteins did not overlap in cells exposed to $\mathrm{TiO}_{2}$ NPs and MWCNTs [93] but regulated pathways were essentially the same. Similarly, gene regulation coincided very well with exoproteome profiles obtained by exposure of A549 cells with $12 \mathrm{~nm} \mathrm{SiO}{ }_{2}$ particles [78]. Concordant pathway regulation pattern was also obtained in transcriptomics and proteomics studies of macrophages exposed to $\mathrm{Cu}, \mathrm{CuO}$, and $\mathrm{TiO}_{2} \mathrm{NPs}[61$, 77]. The sensitivity of the different omics technologies may however differ. Gioria et al. used proteomics and metabolomics and identified different regulation profiles of 5 and $30 \mathrm{~nm} \mathrm{Au} \mathrm{NPs} \mathrm{only} \mathrm{by} \mathrm{proteomics} \mathrm{[59].}$

Inflammation and oxidative stress were reported with different frequencies in transcriptomics and proteomics studies. Different exposure concentrations in the studies is not very likely the explanation as little dose dependency in the regulated genes was observed for $\mathrm{SiO}_{2} \mathrm{NPs}$ [78]. $\mathrm{TiO}_{2}$ and $\mathrm{ZnO}$ particles also caused similar regulation pattern over a wide range of concentrations $(5-50 \mu \mathrm{g} / \mathrm{ml}$ for $\mathrm{TiO}_{2}$ and $0.5-5 \mu \mathrm{g} / \mathrm{ml}$ for $\mathrm{ZnO}$ [94]. Another influencing factor may be exposure time. A time-dependent transcriptomics study of various NPs showed that upon short contact with NPs (1-3 h), cells reacted to different types of NPs in a similar way. After $24 \mathrm{~h}$ a particle-specific reaction pattern was seen [93]. When only studies are included, where $\geq 3$ particles were evaluated $\left(\mathrm{SiO}_{2}, \mathrm{TiO}_{2}\right.$, CNTs) it is also found that immune effects are reported in the transcriptomics but not in the proteomics in vitro studies. The comparison between transcriptomics and proteomics data from $\mathrm{TiO}_{2}$ rods and MWCNTs by Tilton et al. confirmed that regulation of immune processes was more pronounced in gene regulation than in protein regulation. Apparently, NP-induced changes in transcripts of inflammatory genes do not obligatorily result in changes of protein levels [93]. The reduced reporting of immune regulation in proteomics studies is also seen in the in vivo studies on $\mathrm{TiO}_{2}$ exposures (Table 2). NPs were applied by different routes and inflammation was reported in 5/7 transcriptomics and $2 / 5$ proteomics studies, while oxidative stress related pathways were identified in $1 / 7$ transcriptomics and $4 / 5$ proteomics studies. The comparison is subjected to certain bias. The 5 proteomics studies were published by only two research groups. Lack of regulation of inflammation in transcriptomics was seen in studies where effects in organs far from the application of the NPs were analysed, in specific, changes in the ovary following intragastral application and changes in the liver of offspring after intratracheal application of the NPs to pregnant mice. The metaanalysis by Nikota et al. on $\mathrm{TiO}_{2}$ NPs and CNT confirmed regulation of inflammation but 
not of oxidative stress by transcriptomics [51]. Data integration is a critical and relevant factor for the outcome of omics studies. Most researchers use Ingenuity Pathway Analysis (IPA) that allows handling of transcriptomics, proteomics and metabolomics data. Free software programs (e.g. Integrated Molecular Pathway Level Analysis, IMPaLA) have similar capacities to analyze data obtained by all these techniques [95]. IMPALA and iPEAP (integrative Pathway Enrichment Analysis Platform) also allow to identify additional pathways from combined datasets originating from different omics techniques. The common software systems integrate data either based on pathway or biochemical ontology, on biological networks or on analysis of empirical correlations [96]. The analysis programs vary in outcome of the analysis (e.g. identification of additional pathways, functional enrichment analysis, differential correlation analysis, etc.), accepted inputs (e.g. genomic, proteomic, metabolomic, biochemical platform independent), user platform (e.g. software, web-based) and difficulty to use. Empirical correlation analysis is usually based on $\mathrm{R}$ package and more difficult to perform than pathway enrichment analysis.

The relatively high number of transcriptomics studies on cellular effects of $20 \mathrm{~nm} \mathrm{Ag} \mathrm{NPs} \mathrm{can} \mathrm{show} \mathrm{to} \mathrm{which}$ extent study results using the same technology, particles and cells vary. Different pathway regulation pattern were reported by six groups that evaluated the effect of $20 \mathrm{~nm} \mathrm{Ag} \mathrm{NPs} \mathrm{by} \mathrm{transcriptomics.} \mathrm{All} \mathrm{of} \mathrm{them} \mathrm{analysed}$ samples at various time points and all but one included $24 \mathrm{~h}$ as a sampling point. Two studies evaluated human dermal fibroblasts at high concentrations and two others studies HepG2 hepatocytes at low concentrations. In the fibroblast studies, but not in the HepG2 studies, there was overlap in the reported pathways. Interestingly, both studies on fibroblasts did not report regulation of oxidative stress, which was reported in most of the other studies on Ag NPs. Effects on fibroblasts were verified by phenotypic assays in one study of fibroblast and in one of the studies on HepG2 cells. Taking into consideration that interarray reproducibility may be low [17], disparate results can be due to the use of different array or pathway analysis platforms. In case of identification of additional pathways, as in the fibroblasts study, sensitivity of the cells could be different. Regarding the HepG2 studies, the different sampling times ( $\leq 24 \mathrm{~h}$ vs. $\geq 24 \mathrm{~h}$ ) and different exposure concentrations may explain the difference. The comparison may indicate that transcriptomics data are particularly sensitive to the exposure conditions.

As particle handling and biological parameters (passage of cells, preparation of particles, exposure, use of exposure medium) may influence the results, only studies that included more than one particles or $>1$ cell type were analysed to reveal particle- or cell-specific regulation pattern.

\section{Influence of cell types}

Cells differ in their resistance to oxidative stress, in the proliferation rate, in the reaction to inflammatory stimuli and their reaction to NPs, e.g. CNTs [97]. Particularly for particles, the ability of cells for phagocytosis appears to be important. Phagocytes ingest NPs to a higher degree and the particle accumulation may affect the physiology of phagocytes more than that of epithelial cells [98]. The reported regulation patterns, however, do not support this hypothesis as similar patterns were published for macrophages and epithelial cells exposed to ZnO NPs [94, 99]. Phagocytosis also appears not to be regulated by exposure to NPs. Only two proteomics and one transcriptomics studies reported regulation of phagocytosis [93, 100, 101], while the majority of transcriptomics (6) and proteomics (5) studies did not report this. The low importance of the cell type in pathway regulation was corroborated by a meta-analysis on regulation in Caco2, THP-1, and small airway cells by $\mathrm{TiO}_{2}$ and CNTs. The authors concluded that regulation pattern were more particle-specific than cell-specific [93].

Differences in contact between particles and cells growing either adherent or non-adherent, may affect regulation. Although cells growing in suspension culture also settle on the bottom of the plate after a certain time, they do not form confluent monolayers and this may lead to different exposure doses. Differences in cellular particle uptake between adherent and non-adherent growing cells have been reported for instance for CNTs [102]. The reduced uptake could explain the different cytotoxicity of CNTs in cells growing in suspension compared to adherent cells [97]. Consistent with the hypothesis of a different reaction of adherent and non-adherent cells, alumina NPs showed a dose-dependent and timedependent increase in cytotoxicity for adherent cells but only dose-dependent increase for suspension cells [103]. The majority of cells that were used in the studies (Table 1) were adherent growing cells and only two studies analysed cells growing in suspension in parallel to adherent growing cells $[94,104] . \mathrm{Fe}_{3} \mathrm{O}_{4}$ were tested in THP-1 monocytes (growing in suspension) and in adherent growing HepG2 hepatocytes by transcriptomics. Since lack of contact may be a reason for a decreased cellular response, cellular uptake of the particles was determined by Prussian Blue staining. Despite lower uptake by THP-1 cells, more genes than in HepG2 cells were regulated, which suggests a higher sensitivity of the immune cells to exposure to $\mathrm{Fe}_{3} \mathrm{O}_{4}$ particles. The other transcriptomics study, however, did not identify prominent differences between Jurkat lymphocytes (suspension) and macrophages (adherent growth) when exposed to $\mathrm{ZnO}$ NPs. In this case different cell contact due to particle sedimentation was irrelevant because the authors concluded 
that the actions were caused by dissolved $\mathrm{Zn}^{2+}$ ions and not by intact particles.

\section{Influence of particle properties}

Biological effects are influenced by a variety of parameters, mainly by material, size, surface properties, and shape [105]. A particle-specific regulation pattern would not be unexpected but responses to plain particles of different material in transcriptomics and proteomics studies (e.g. $\mathrm{Fe}_{2} \mathrm{O}_{3} / \mathrm{SiO}_{2} / \mathrm{ZnO} ; \mathrm{WC} / \mathrm{WCC} ; \mathrm{SWCNT} / \mathrm{MWCNT}$; $\mathrm{TiO}_{2} / \mathrm{CuO} ; \mathrm{ZnO} / \mathrm{ZrO}$ ) in a given cell line after $\geq 24 \mathrm{~h}$ were uniform $[53,77,100,101,106,107]$. Although the proteomics study on the effect of $\mathrm{Au}, \mathrm{Cu}$ and CdTe NPs in THP-1 cells suggested particle-specific regulation [108], other studies do not give indication for particle-specific regulation in RAW 264.7 macrophages [61, 77, 101]. After pulmonary application, $\mathrm{C}_{60}$ fullerenes and $\mathrm{NiO} \mathrm{NPs}$ regulated particle-specific and common transcriptomic pathways in mouse lungs [55]. Furthermore, all omics studies of pulmonary application of NPs, irrespective of the material, reported regulation of immune system and inflammation. These results support the hypothesis of a cell-/ organ-specific reaction pattern. It might be possible that the invasive application, in general intratracheal instillation, increased the propensity for inflammation. The absence of pulmonary inflammation after inhaled $\mathrm{TiO}_{2}$ NPs versus instilled NPs supports this assumption [109].

When particles in different sizes and surface properties were studied the following can be concluded. Transcriptomics studies identified mainly quantitative differences in the regulation by particles of different size. Typically, smaller particles caused an effect, while the larger particles did not (e.g. [80], Table 1). Different pathways (oxidative stress vs. cell signaling), by contrast, have been reported for 20 and $100 \mathrm{~nm} \mathrm{Au} \mathrm{NPs} \mathrm{in} \mathrm{proteomics} \mathrm{[60].}$ Surface qualities did not markedly influence the regulation pattern according to transcriptomics and proteomics studies. Cellular effects of differently functionalized $\mathrm{Au}$ particles and bare and differently functionalized $\mathrm{Fe}_{3} \mathrm{O}_{4}$ particles in transcriptomics as well as action of coated and plain $\mathrm{TiO}_{2}$ and plain and pegylated SWCNTs support the missing effect of surface properties (Table 1). Comparative metabolomics study on intratracheally instilled polystyrene and polymer particles demonstrated a correlation between surface hydrophobicity and extent of the inflammatory reaction. This finding is consistent with results obtained by conventional testing where particles with hydrophobic surface induced higher immune response than those with hydrophilic surface [110].

Studies of spherical and rod-like $\mathrm{CuO}$ suggest a small influence of shape on gene regulation, with rod-like NPs showing a stronger pro-inflammatory effect than spherical particles [111]. Also the meta-analysis by Tilton et al. concluded that exposure to $\mathrm{TiO}_{2}$ rods and CNTs induced a particle-specific regulation pattern [93]. This leads to the hypothesis that particle-specific regulation may occur for non-spherical compared to spherical particles.

In summary, particle parameters caused rather quantitative than qualitative differences in the regulation pattern.

\section{Correlation to phenotypic assays}

For evaluation of the use of omics technologies in toxicity testing of NPs it is important to know the extent to which pathway regulation corresponds to phenotypic changes. The best method for this comparison is the choice of a phenotypic assay platform capable to analyse multiple parameters in the same cell population. Conventional screening comprises a panel of colorimetric, fluorometric and luminescent test methods for the detection of apoptosis, membrane damage, proliferation, lysosome function, etc. in parallel exposures. Interference of NPs may occur in one or more of these assays [112, 113]. Highcontent screening systems (HCS) have the advantage that they combine various fluorescent assays with detection of morphological changes by bright field microscopy. This way, several parameters can be analysed in parallel and inconsistency between signal and cell morphology can be discerned.

The suggested assay panel representing the most common targets for a comprehensive analysis of NP toxicity included: (i) cytotoxicity (proliferation, membrane leakage and integrity, ATP content, mitochondrial potential, metabolic activity, calcium flux, apoptosis), (ii) genotoxicity by DNA cleavage (micronucleus assay), (iii) inflammation (interleukin 1, 8 or tumor-necrosis factor alpha, nuclear factor kappa B, or activator protein-1 activation), (iv) oxidative stress (ROS generation or GSH), and (v) fibrotic potential (tumor growth factor-1 beta, collagens 1 and 3 and metalloproteinase activity) [114]. These categories correspond in essence to the pathway regulation classes in Table 1. Differences include the lack of fibrotic potential and genotoxic potential in the table and the addition of proliferation, morphology, vesicles and signaling pathways. Another set of targets for the toxicity screening of NPs, namely proliferation, apoptosis, inflammation and genotoxicity, has also been suggested [115].

The available HCS data are ambiguous regarding cell-specific reaction to NPs. CdTe NPs induced quantitatively different responses in differentiated and undifferentiated murine neuronal cells. Human and murine neuroblastoma cells, neural progenitor cells and neural stem cells reacted in different way to iron oxide NPs. Furthermore, $50 \mathrm{~nm}$ amine-functionalized polystyrene NPs induced apoptosis in a variety of cells (astrocytes, HEK293, A549, HepG2, and hMECD) but not in RAW 
Table 3 Limitations that hinder the broad use of omics technologies in nanotoxicology

\begin{tabular}{ll}
\hline Independent from the technology & Technology linked \\
\hline Lack of standardization of particle exposure & Request for high sample quality (freezing, protection against degradation) \\
Sample pre-treatment & Expertise in bioinformatics needed for data analysis \\
Cell type used for testing & Lack of standardization of sample preparation \\
Medium composition & Predictive value of the omics techniques not entirely clear \\
Relevant concentration range & \\
\hline
\end{tabular}

264.7 macrophages. Lack of cell-specific action, on the other hand was reported by other studies. Membrane damage and mitochondrial damage induced by $\mathrm{TiO}_{2}$, $\mathrm{CeO}_{2}$, and $\mathrm{ZnO}$ in sizes between 5 and $20 \mathrm{~nm}$ was similar in BEAS-2B and macrophages [116-119] and $35 \mathrm{~nm}$ $\mathrm{Fe}_{3} \mathrm{O}_{4}$ NPs produced the same profile in murine fibroblasts and simian COS cells [120].

The potential of screening by phenotypic assays is limited in the identification of new modes of action. Except for the cytotoxicity screening assays, they can only detect a specific cellular effect and the characterization of particle effects depends on the selection of the right assays. This can be seen as disadvantage compared to omics techniques in the untargeted form.

\section{Conclusions}

Omics platforms could be useful to identify new pathways and mechanisms in nanotoxicity not visible in conventional testing. This is, however, not always the case for NPs. Studies of polystyrene particles identified corresponding targets by conventional assays and whole genome transcription arrays [53, 105, 121]. Transcriptomic analysis, on the other hand, identified adverse cellular effects at lower concentrations than conventional cytotoxicity screening based on ATP content, dehydrogenase activity and cell impedance monitoring [78]. The comparison is complicated by the fact that the regulation of genes indicates a potential damage but does not prove that cell damage will actually occur. Researchers reported different regulation patterns by similar NPs in the same cells tested with the same technologies. As omics data were confirmed by phenotypic assays, disparate results between research groups may be caused by different exposure conditions. More frequently reported regulation of inflammation in cellular transcriptomics than proteomics studies, on the other hand, may be linked to the technology. General (technology-independent) problems with in vitro testing of NPs and issues related to omics technologies that limit their application in nanotoxicity testing are listed in Table 3 . Different particle exposure conditions have been suspected to be the reason for inter-study differences in phenotypic assays.
In order to avoid this problem, standard operation procedures (SOPs) for preparation of particle suspensions, use of cell lines and preparation of cells have been developed (see for instance overview https://www.nanopartikel. info/nanoinfo/methodik/401-arbeitsanweisung). The general use of these SOPs by all researchers may decrease variations between studies. The use of confirmatory assays (e.g. another omics technique, phenotypic assays) is important to demonstrate study quality and verify pathway regulation.

\section{Abbreviations}

Ag: silver; Au: gold; BAL: bronchoalveolar lavage fluid; CdTe: cadmium tellurite; CNT: carbon nanotube; Co: cobalt; Cu: copper; DCs: dendritic cells; Diff:: differentiated; ECM: extracellular matrix; ER: endoplasmic reticulum; ESI: electrospray ionization; Exp.: exposure; $\mathrm{Fe}_{\mathrm{y}} \mathrm{O}_{\mathrm{y}}$ : iron oxide; FGF-2: fibroblast growth factor 1; FTIR: Fourrier transform ion cyclotron resonance; GC: gas chromatography; GSH: glutathione; HCS: high content screening; HGF: hepatic growth factor; HPLC: high performance liquid chromatography; HSP: heat shock protein; id: intradermal; ig: intragastral; IMPaLA: Integrated Molecular Pathway Level Analysis; inhal: inhalation; ip: intraperitoneal; IPA: Ingenuity Pathway Analysis; iPEAP: integrative Pathway Enrichment Analysis Platform; it: intratracheal instillation; iv: intravenous; LC: liquid chromatography; MALDI: matrix-assisted laser desorption ionization; MAPK: mitogen activated protein kinase; MSCs: mesenchymal stem cells; MS: mass spectrometry; MWCNT: multi-walled carbon nanotube; NfkB: nuclear factor kappa B; NMR: nuclear magnetic resonance; NP: nanoparticle; oroph: oropharyngeal aspiration; ox: oxidative; PAK: p21 activated kinases; RISC: RNA-induced silencing complex; SDS: sodium dodecyl sulfate; $\mathrm{SiO}_{2}$ : silicium oxide; SOP: standard operation procedures; SWCNT: single-walled carbon nanotube; TFG- $\beta$ : tumor growth factor beta; Tech: technique; $\mathrm{TiO}_{2}$ : titanium dioxide; TOF: time of flight; WC: tungsten carbide; ZnO: zinc oxide; ZrO: zirconium oxide.

\section{Acknowledgements \\ Not applicable. \\ Competing interests \\ The authors declare that they have no competing interests.}

Availability of data and materials

Not applicable.

Consent for publication

Not applicable.

Ethics approval and consent to participate

Not applicable.

Funding

Studies were supported by the Austrian Science Fund Grant P 22576-B18. 


\section{Publisher's Note}

Springer Nature remains neutral with regard to jurisdictional claims in published maps and institutional affiliations.

Received: 5 July 2017 Accepted: 12 November 2017

Published online: 21 November 2017

\section{References}

1. Oberdorster G. Pulmonary effects of inhaled ultrafine particles. Int Arch Occup Environ Health. 2000;74:1-8.

2. Walters C, Pool E, Somerset V. Nanotoxicology: a review. In: Soloneski $\mathrm{S}$, Larramendy M, editors. Toxicology - new aspects to this scientific conundrum. Rijeka: inTech; 2016.

3. Hartung T, van Vliet E, Jaworska J, Bonilla L, Skinner N, Thomas R. Systems toxicology. Altex. 2012;29:119-28.

4. Zook JM, Maccuspie RI, Locascio LE, Halter MD, Elliott JT. Stable nanoparticle aggregates/agglomerates of different sizes and the effect of their size on hemolytic cytotoxicity. Nanotoxicology. 2011;5:517-30.

5. Fröhlich E. Cellular targets and mechanisms in the cytotoxic action of non-biodegradable engineered nanoparticles. Curr Drug Metab. 2013;14:976-88.

6. Kim JS, Adamcakova-Dodd A, O'Shaughnessy PT, Grassian VH, Thorne PS. Effects of copper nanoparticle exposure on host defense in a murine pulmonary infection model. Part Fibre Toxicol. 2011:8:29.

7. Fröhlich $E$. The role of surface charge in cellular uptake and cytotoxicity of medical nanoparticles. Int J Nanomed. 2012;7:5577-91.

8. Wang W, Shi Q, Mattes WB, Mendrick DL, Yang X. Translating extracellular microRNA into clinical biomarkers for drug-induced toxicity: from high-throughput profiling to validation. Biomark Med. 2015;9:1177-88

9. Yamamoto M, Singh A, Sava F, Pui M, Tebbutt SJ, Carlsten C. MicroRNA expression in response to controlled exposure to diesel exhaust: attenuation by the antioxidant $\mathrm{N}$-acetylcysteine in a randomized crossover study. Environ Health Perspect. 2013;121:670-5.

10. Choudhuri S. Small noncoding RNAs: biogenesis, function, and emerging significance in toxicology. J Biochem Mol Toxicol. 2010;24:195-216.

11. Ehrlich M. DNA hypomethylation in cancer cells. Epigenomics. 2009:1:239-59.

12. Bannister AJ, Kouzarides T. Regulation of chromatin by histone modifications. Cell Res. 2011:21:381-95.

13. Ropero S, Esteller M. The role of histone deacetylases (HDACs) in human cancer. Mol Oncol. 2007:1:19-25.

14. You JS, Jones PA. Cancer genetics and epigenetics: two sides of the same coin? Cancer Cell. 2012;22:9-20.

15. Kurdyukov S, Bullock M. DNA Methylation analysis: choosing the right method. Biology. 2016;5:3.

16. Ezkurdia I, Juan D, Rodriguez JM, Frankish A, Diekhans M, Harrow J, et al. Multiple evidence strands suggest that there may be as few as 19,000 human protein-coding genes. Hum Mol Genet. 2014;23:5866-78.

17. Tarca AL, Romero R, Draghici S. Analysis of microarray experiments of gene expression profiling. Am J Obstet Gynecol. 2006;195:373-88.

18. Lai ZW, Yan Y, Caruso F, Nice EC. Emerging techniques in proteomics for probing nano-bio interactions. ACS Nano. 2012;6:10438-48.

19. Zhang Y, Fonslow BR, Shan B, Baek MC, Yates JR 3rd. Protein analysis by shotgun/bottom-up proteomics. Chem Rev. 2013;113:2343-94.

20. Chen T, Zhao J, Ma J, Zhu Y. Web resources for mass spectrometrybased proteomics. Genom Proteom Bioinf. 2015;13:36-9.

21. Monopoli MP, Walczyk D, Campbell A, Elia G, Lynch I, Bombelli FB, et al. Physical-chemical aspects of protein corona: relevance to in vitro and in vivo biological impacts of nanoparticles. J Am Chem Soc. 2011;133:2525-34.

22. Rahman M, Laurent S, Tawil N, Yahia L, Mahmoudi M. Nanoparticle and protein corona. In: Rahman M, Laurent S, Tawil N, Yahia L, Mahmoudi M, editors. Protein-nanoparticle interactions, vol. 15., The bio-nano interface springer series in biophysicsBerlin: Springer; 2013.

23. Cai $X$, Ramalingam $\mathrm{R}$, Wong HS, Cheng J, Ajuh $\mathrm{P}$, Cheng $\mathrm{SH}$, et al. Characterization of carbon nanotube protein corona by using quantitative proteomics. Nanomedicine. 2013:9:583-93.
24. Pisani C, Gaillard JC, Odorico M, Nyalosaso JL, Charnay C, Guari Y, et al. The timeline of corona formation around silica nanocarriers highlights the role of the protein interactome. Nanoscale. 2017:9:1840-51.

25. Schaffler M, Semmler-Behnke M, Sarioglu H, Takenaka S, Wenk A, Schleh $C$, et al. Serum protein identification and quantification of the corona of 5, 15 and $80 \mathrm{~nm}$ gold nanoparticles. Nanotechnology. 2013;24:265103.

26. Schottler S, Becker G, Winzen S, Steinbach T, Mohr K, Landfester K, et al. Protein adsorption is required for stealth effect of poly(ethylene glycol)- and poly(phosphoester)-coated nanocarriers. Nat Nanotechnol. 2016;11:372-7.

27. Shannahan JH, Lai X, Ke PC, Podila R, Brown JM, Witzmann FA. Silver nanoparticle protein corona composition in cell culture media. PLoS ONE. 2013:8:e74001.

28. Vogt C, Pernemalm M, Kohonen P, Laurent S, Hultenby K, Vahter M, et al. Proteomics analysis reveals distinct corona composition on magnetic nanoparticles with different surface coatings: implications for interactions with primary human macrophages. PLOS ONE. 2015;10:e0129008.

29. Wohlleben W, Driessen MD, Raesch S, Schaefer UF, Schulze C, Vacano $B$, et al. Influence of agglomeration and specific lung lining lipid/ protein interaction on short-term inhalation toxicity. Nanotoxicology. 2016;10:970-80

30. De La Luz-Hdez K. Metabolomics and mammalian cell culture. In: Roessner U, editor. Metabolomics. Rijeka: InTech Europe; 2012. p. 3-18.

31. Ramirez T, Daneshian M, Kamp H, Bois FY, Clench MR, Coen M, et al. Metabolomics in toxicology and preclinical research. Altex. 2013;30:209-25.

32. Murgia A, Mancuso L, Manis C, Caboni P, Cao G. GC-MS metabolomics analysis of mesenchymal stem cells treated with copper oxide nanoparticles. Toxicol Mech Methods. 2016;26:611-9.

33. Esther RJ, Bhattacharya R, Ruan M, Bolander ME, Mukhopadhyay D, Sarkar G, et al. Gold nanoparticles do not affect the global transcriptional program of human umbilical vein endothelial cells: a DNA-microarray analysis. J Biomed Nanotechnol. 2005;1:328-35.

34. Blaber SP, Hill CJ, Webster RA, Say JM, Brown LJ, Wang SC, et al. Effect of labeling with iron oxide particles or nanodiamonds on the functionality of adipose-derived mesenchymal stem cells. PLoS ONE. 2013;8:e52997.

35. Gong C, Tao G, Yang L, Liu J, Liu Q, Zhuang Z. SiO(2) nanoparticles induce global genomic hypomethylation in $\mathrm{HaCaT}$ cells. Biochem Biophys Res Commun. 2010;397:397-400.

36. Lu X, Miousse IR, Pirela SV, Melnyk S, Koturbash I, Demokritou P. Shortterm exposure to engineered nanomaterials affects cellular epigenome. Nanotoxicology. 2016;10:140-50.

37. Patil NA, Gade WN, Deobagkar DD. Epigenetic modulation upon exposure of lung fibroblasts to $\mathrm{TiO}_{2}$ and $\mathrm{ZnO}$ nanoparticles: alterations in DNA methylation. Int J Nanomed. 2016;11:4509-19.

38. Qian Y, Zhang J, Hu Q, Xu M, Chen Y, Hu G, et al. Silver nanoparticleinduced hemoglobin decrease involves alteration of histone 3 methylation status. Biomaterials. 2015;70:12-22.

39. Lu X, Miousse IR, Pirela SV, Moore JK, Melnyk S, Koturbash I, et al. In vivo epigenetic effects induced by engineered nanomaterials: a case study of copper oxide and laser printer-emitted engineered nanoparticles. Nanotoxicology. 2016;10:629-39.

40. Tabish AM, Poels K, Byun HM, Luyts K, Baccarelli AA, Martens J, et al. Changes in DNA methylation in mouse lungs after a single intratracheal administration of nanomaterials. PLoS ONE. 2017:12:e0169886.

41. Sule N, Singh R, Srivastava DK. Alternative modes of binding of recombinant human histone deacetylase 8 to colloidal gold nanoparticles. J Biomed Nanotechnol. 2008;4:463-8.

42. Choi AO, Brown SE, Szyf M, Maysinger D. Quantum dot-induced epigenetic and genotoxic changes in human breast cancer cells. J Mol Med (Berl). 2008;86:291-302

43. Chen T, Yan J, Li Y. Genotoxicity of titanium dioxide nanoparticles. J Food Drug Anal. 2014;22:95-104.

44. Kwon JY, Koedrith P, Seo YR. Current investigations into the genotoxicity of zinc oxide and silica nanoparticles in mammalian models in vitro and in vivo: carcinogenic/genotoxic potential, relevant mechanisms and biomarkers, artifacts, and limitations. Int J Nanomed. 2014;9(Suppl 2):271-86.

45. Akhtar MJ, Kumar S, Alhadlaq HA, Alrokayan SA, Abu-Salah KM, Ahamed M. Dose-dependent genotoxicity of copper oxide nanoparticles 
stimulated by reactive oxygen species in human lung epithelial cells. Toxicol Ind Health. 2016;32:809-21.

46. Alarifi S, Ali D, Verma A, Alakhtani S, Ali BA. Cytotoxicity and genotoxicity of copper oxide nanoparticles in human skin keratinocytes cells. Int J Toxicol. 2013;32:296-307.

47. Awasthi K, Awasthi A, Verma R, Kumar N, Roy P, Awasthi K, et al. Cytotoxicity, genotoxicity and alteration of cellular antioxidant enzymes in silver nanoparticles exposed CHO cells. RSC Adv. 2015;5:34927-35.

48. Awasthi K, Verma R, Awasthi A, Soni I, Awasthi K, John P. In vivo genotoxic assessment of silver nanoparticles in liver cells of Swiss albino mice using comet assay. Adv Mater Lett. 2015;6:187-93.

49. Song MF, Li YS, Kasai H, Kawai K. Metal nanoparticle-induced micronuclei and oxidative DNA damage in mice. J Clin Biochem Nutr. 2012;50:211-6.

50. Mrakovcic M, Meindl C, Leitinger G, Roblegg E, Fröhlich E. Carboxylated short single-walled carbon nanotubes but not plain and multi-walled short carbon nanotubes show in vitro genotoxicity. Toxicol Sci. 2015;144:114-27.

51. Nikota J, Williams A, Yauk CL, Wallin H, Vogel U, Halappanavar S. Metaanalysis of transcriptomic responses as a means to identify pulmonary disease outcomes for engineered nanomaterials. Part Fibre Toxicol. 2016:13:25.

52. Huang Y, Lu X, Ma J. Toxicity of silver nanoparticles to human dermal fibroblasts on microRNA level. J Biomed Nanotechnol. 2014;10:3304-17.

53. Fröhlich E, Meindl C, Wagner K, Leitinger G, Roblegg E. Use of whole genome expression analysis in the toxicity screening of nanoparticles. Toxicol Appl Pharmacol. 2014;280:272-84.

54. Waters KM, Masiello LM, Zangar RC, Tarasevich BJ, Karin NJ, Quesenberry RD, et al. Macrophage responses to silica nanoparticles are highly conserved across particle sizes. Toxicol Sci. 2009;107:553-69.

55. Fujita K, Horie M, Kato H, Endoh S, Suzuki M, Nakamura A, et al. Effects of ultrafine $\mathrm{TiO}_{2}$ particles on gene expression profile in human keratinocytes without illumination: involvement of extracellular matrix and cell adhesion. Toxicol Lett. 2009;191:109-17.

56. Lee SH, Pie J, Kim Y, Lee H, Son S, Kim M. Effects of zinc oxide nanoparticles on gene expression profile in human keratinocytes. Mol Cell Toxicol. 2012;8:113.

57. Oh JH, Son MY, Choi MS, Kim S, Choi AY, Lee HA, et al. Integrative analysis of genes and miRNA alterations in human embryonic stem cells-derived neural cells after exposure to silver nanoparticles. Toxicol Appl Pharmacol. 2016;299:8-23.

58. Georgantzopoulou A, Serchi T, Cambier S, Leclerca CC, Renaut J, Shao J, et al. Effects of silver nanoparticles and ions on a co-culture model for the gastrointestinal epithelium. Part Fibre Toxicol. 2016;13:9.

59. Gioria S, Lobo Vicente J, Barboro P, La Spina R, Tomasi G, Urban P, et al. A combined proteomics and metabolomics approach to assess the effects of gold nanoparticles in vitro. Nanotoxicology. 2016;10:736-48.

60. Verano-Braga T, Miethling-Graff R, Wojdyla K, Rogowska-Wrzesinska A, Brewer JR, Erdmann H, et al. Insights into the cellular response triggered by silver nanoparticles using quantitative proteomics. ACS Nano. 2014;8:2161-75.

61. Triboulet S, Aude-Garcia C, Carriere M, Diemer H, Proamer F, Habert A, et al. Molecular responses of mouse macrophages to copper and copper oxide nanoparticles inferred from proteomic analyses. Mol Cell Proteom. 2013;12:3108-22.

62. Ju L, Zhang G, Zhang X, Jia Z, Gao X, Jiang Y, et al. Proteomic analysis of cellular response induced by multi-walled carbon nanotubes exposure in A549 cells. PLoS ONE. 2014;9:e84974.

63. Zhang Y, Xu Y, Li Z, Chen T, Lantz SM, Howard PC, et al. Mechanistic toxicity evaluation of uncoated and PEGylated single-walled carbon nanotubes in neuronal PC12 cells. ACS Nano. 2011;5:7020-33.

64. Boyles MS, Ranninger C, Reischl R, Rurik M, Tessadri R, Kohlbacher O, et al. Copper oxide nanoparticle toxicity profiling using untargeted metabolomics. Part Fibre Toxicol. 2016;13:49.

65. Foldbjerg R, Irving ES, Hayashi Y, Sutherland DS, Thorsen K, Autrup H, et al. Global gene expression profiling of human lung epithelial cells after exposure to nanosilver. Toxicol Sci. 2012;130:145-57.

66. Zhang T, Stilwell JL, Gerion D, Ding L, Elboudwarej O, Cooke PA, et al. Cellular effect of high doses of silica-coated quantum dot profiled with high throughput gene expression analysis and high content cellomics measurements. Nano Lett. 2006;6:800-8.
67. Okoturo-Evans O, Dybowska A, Valsami-Jones E, Cupitt J, Gierula M, Boobis AR, et al. Elucidation of toxicity pathways in lung epithelial cells induced by silicon dioxide nanoparticles. PLoS ONE. 2013;8:e72363.

68. Yang X, Liu J, He H, Zhou L, Gong C, Wang X, et al. $\mathrm{SiO}_{2}$ nanoparticles induce cytotoxicity and protein expression alteration in $\mathrm{HaCaT}$ cells. Part Fibre Toxicol. 2010;7:1.

69. Xu L, Shi C, Shao A, Li X, Cheng X, Ding R, et al. Toxic responses in rat embryonic cells to silver nanoparticles and released silver ions as analyzed via gene expression profiles and transmission electron microscopy. Nanotoxicology. 2015;9:513-22.

70. Ng CT, Yung LY, Swa HL, Poh RW, Gunaratne J, Bay BH. Altered protein expression profile associated with phenotypic changes in lung fibroblasts co-cultured with gold nanoparticle-treated small airway epithelial cells. Biomaterials. 2015;39:31-8.

71. Gioria S, Chassaigne H, Carpi D, Parracino A, Meschini S, Barboro P, et al. A proteomic approach to investigate AuNPs effects in Balb/3T3 cells. Toxicol Lett. 2014;228:111-26.

72. Edelmann MJ, Shack LA, Naske CD, Walters KB, Nanduri B. SILAC-based quantitative proteomic analysis of human lung cell response to copper oxide nanoparticles. PLoS ONE. 2014;9:e114390.

73. Cha MH, Rhim T, Kim KH, Jang AS, Paik YK, Park CS. Proteomic identification of macrophage migration-inhibitory factor upon exposure to $\mathrm{TiO}_{2}$ particles. Mol Cell Proteom. 2007;6:56-63.

74. Decan N, Wu D, Williams A, Bernatchez S, Johnston M, Hill M, et al. Characterization of in vitro genotoxic, cytotoxic and transcriptomic responses following exposures to amorphous silica of different sizes. Mutat Res Genet Toxicol Environ Mutagen. 2016;796:8-22.

75. Kawata K, Osawa M, Okabe S. In vitro toxicity of silver nanoparticles at noncytotoxic doses to HepG2 human hepatoma cells. Environ Sc Technol. 2009;43:6046-51.

76. Mei N, Zhang Y, Chen Y, Guo X, Ding W, Ali SF, et al. Silver nanoparticleinduced mutations and oxidative stress in mouse lymphoma cells. Environ Mol Mutagen. 2012;53:409-19.

77. Triboulet S, Aude-Garcia C, Armand L, Collin-Faure V, Chevallet M, Diemer $\mathrm{H}$, et al. Comparative proteomic analysis of the molecular responses of mouse macrophages to titanium dioxide and copper oxide nanoparticles unravels some toxic mechanisms for copper oxide nanoparticles in macrophages. PLoS ONE. 2015;10:e0124496.

78. Pisani C, Gaillard JC, Nouvel V, Odorico M, Armengaud J, Prat O. Highthroughput, quantitative assessment of the effects of low-dose silica nanoparticles on lung cells: grasping complex toxicity with a great depth of field. BMC Genomics. 2015;16:315.

79. Tsai YY, Huang YH, Chao YL, Hu KY, Chin LT, Chou SH, et al. Identification of the nanogold particle-induced endoplasmic reticulum stress by omic techniques and systems biology analysis. ACS Nano. 2011;5:9354-69.

80. Lim DH, Jang J, Kim S, Kang T, Lee K, Choi IH. The effects of sub-lethal concentrations of silver nanoparticles on inflammatory and stress genes in human macrophages using cDNA microarray analysis. Biomaterials. 2012;33:4690-9.

81. Li X, Zhang C, Bian Q, Gao N, Zhang X, Meng Q, et al. Integrative functional transcriptomic analyses implicate specific molecular pathways in pulmonary toxicity from exposure to aluminum oxide nanoparticles. Nanotoxicology. 2016;10:957-69.

82. Moret F, Selvestrel F, Lubian E, Mognato M, Celotti L, Mancin F, et al. PEGylation of ORMOSIL nanoparticles differently modulates the in vitro toxicity toward human lung cells. Arch Toxicol. 2015;89:607-20.

83. Paris D, Melck D, Longo A, Napoletano S, Carotenuto G, Nicolais L, et al. Metabolic response of SH-SY5Y cells to gold nanoparticles by NMR-based metabolomics analyses. Biomed Phys Eng Express. 2016:2:045003.

84. Liao M, Liu H. Gene expression profiling of nephrotoxicity from copper nanoparticles in rats after repeated oral administration. Environ Toxicol Pharmacol. 2012;34:67-80.

85. Rahman L, Wu D, Johnston M, William A, Halappanavar S. Toxicogenomics analysis of mouse lung responses following exposure to titanium dioxide nanomaterials reveal their disease potential at high doses. Mutagenesis. 2017;32:59-76.

86. Husain M, Saber AT, Guo C, Jacobsen NR, Jensen KA, Yauk CL, et al. Pulmonary instillation of low doses of titanium dioxide nanoparticles 
in mice leads to particle retention and gene expression changes in the absence of inflammation. Toxicol Appl Pharmacol. 2013;269:250-62.

87. Cui Y, Liu H, Ze Y, Zengli Z, Hu Y, Cheng Z, et al. Gene expression in liver injury caused by long-term exposure to titanium dioxide nanoparticles in mice. Toxicol Sci. 2012;128:171-85.

88. Gao G, Ze Y, Li B, Zhao X, Zhang T, Sheng L, et al. Ovarian dysfunction and gene-expressed characteristics of female mice caused by long-term exposure to titanium dioxide nanoparticles. J Hazard Mater. 2012;243:19-27.

89. Sheng L, Wang L, Sang X, Zhao X, Hong J, Cheng S, et al. Nano-sized titanium dioxide-induced splenic toxicity: a biological pathway explored using microarray technology. J Hazard Mater. 2014;278:180-8.

90. Jackson P, Halappanavar S, Hougaard KS, Williams A, Madsen AM, Lamson JS, et al. Maternal inhalation of surface-coated nanosized titanium dioxide (UV-Titan) in C57BL/6 mice: effects in prenatally exposed offspring on hepatic DNA damage and gene expression. Nanotoxicology. 2013;7:85-96.

91. Dailey LA, Hernandez-Prieto R, Casas-Ferreira AM, Jones MC, RiffoVasquez $Y$, Rodriguez-Gonzalo E, et al. Adenosine monophosphate is elevated in the bronchoalveolar lavage fluid of mice with acute respiratory toxicity induced by nanoparticles with high surface hydrophobicity. Nanotoxicology. 2015;9:106-15.

92. Raj A, Peskin CS, Tranchina D, Vargas DY, Tyagi S. Stochastic mRNA synthesis in mammalian cells. PLoS Biol. 2006;4:e309.

93. Tilton SC, Karin NJ, Tolic A, Xie Y, Lai X, Hamilton RF Jr, et al. Three human cell types respond to multi-walled carbon nanotubes and titanium dioxide nanobelts with cell-specific transcriptomic and proteomic expression patterns. Nanotoxicology. 2014;8:533-48.

94. Tuomela S, Autio R, Buerki-Thurnherr T, Arslan O, Kunzmann A, Andersson-Willman B, et al. Gene expression profiling of immune-competent human cells exposed to engineered zinc oxide or titanium dioxide nanoparticles. PLOS ONE. 2013;8:e68415.

95. Kamburov A, Cavill R, Ebbels TM, Herwig R, Keun HC. Integrated pathway-level analysis of transcriptomics and metabolomics data with IMPaLA. Bioinformatics. 2011;27:2917-8.

96. Wanichthanarak K, Fahrmann JF, Grapov D. Genomic, proteomic, and metabolomic data integration strategies. Biomarker Insights. 2015:10:1-6.

97. Fröhlich E, Meindl C, Höfler A, Leitinger G, Roblegg E. Combination of small size and carboxyl functionalisation causes cytotoxicity of short carbon nanotubes. Nanotoxicology. 2013;7:1211-24.

98. Prietl B, Meindl C, Roblegg E, Pieber TR, Lanzer G, Fröhlich E. Nano-sized and micro-sized polystyrene particles affect phagocyte function. Cell Biol Toxicol. 2014;30:1-16.

99. Moos PJ, Olszewski K, Honeggar M, Cassidy P, Leachman S, Woessner D, et al. Responses of human cells to $\mathrm{ZnO}$ nanoparticles: a gene transcription study. Metallomics. 2011;3:1199-211.

100. Aude-Garcia C, Dalzon B, Ravanat JL, Collin-Faure V, Diemer H, Strub JM, et al. A combined proteomic and targeted analysis unravels new toxic mechanisms for zinc oxide nanoparticles in macrophages. J Proteom. 2016;134:174-85.

101. Duan J, Kodali VK, Gaffrey MJ, Guo J, Chu RK, Camp DG, et al. Quantitative profiling of protein S-glutathionylation reveals redox-dependent regulation of macrophage function during nanoparticle-induced oxidative stress. ACS Nano. 2016;10:524-38.

102. Thurnherr T, Brandenberger $C$, Fischer K, Diener L, Manser P, MaederAlthaus $X$, et al. A comparison of acute and long-term effects of industrial multiwalled carbon nanotubes on human lung and immune cells in vitro. Toxicol Lett. 2011;200:176-86.

103. Yoon D, Woo D, Kim J, Kim M, Kim T, Hwang E, et al. Agglomeration, sedimentation, and cellular toxicity of alumina nanoparticles in cell culture medium. J Nanopart Res. 2011;13:2543-51.

104. Zhang L, Wang X, Zou J, Liu Y, Wang J. Effects of an 11-nm DMSAcoated iron nanoparticle on the gene expression profile of two human cell lines, THP-1 and HepG2. J Nanobiotechnol. 2015;13:3.

105. Fröhlich E, Meindl C, Roblegg E, Griesbacher A, Pieber TR. Cytotoxicity of nanoparticles is influenced by size, proliferation and embryonic origin of the cells used for testing. Nanotoxicology. 2012;6:424-33.

106. Busch W, Kuhnel D, Schirmer K, Scholz S. Tungsten carbide cobalt nanoparticles exert hypoxia-like effects on the gene expression level in human keratinocytes. BMC Genomics. 2010;11:65.
107. Dua P, Chaudhari K, Lee C, Chaudhari N, Hong S, Yu J, et al. Evaluation of toxicity and gene expression changes triggered by oxide nanoparticles. Bull Korean Chem Soc. 2011;32:2051.

108. Tarasova NK, Gallud A, Ytterberg AJ, Chernobrovkin A, Aranzaes JR, Astruc D, et al. Cytotoxic and proinflammatory effects of metal-based nanoparticles on THP-1 monocytes characterized by combined proteomics approaches. J Proteome Res. 2017;16:689-97.

109. Morimoto Y, Izumi H, Yoshiura Y, Tomonaga T, Lee BW, Okada T, et al. Comparison of pulmonary inflammatory responses following intratracheal instillation and inhalation of nanoparticles. Nanotoxicology. 2016;10:607-18.

110. Zhao L, Seth A, Wibowo N, Zhao CX, Mitter N, Yu C, et al. Nanoparticle vaccines. Vaccine. 2014;32:327-37.

111. Piret JP, Vankoningsloo S, Mejia J, Noel F, Boilan E, Lambinon F, et al. Differential toxicity of copper (II) oxide nanoparticles of similar hydrodynamic diameter on human differentiated intestinal Caco-2 cell monolayers is correlated in part to copper release and shape. Nanotoxicology. 2012;6:789-803.

112. Monteiro-Riviere NA, Inman AO, Zhang LW. Limitations and relative utility of screening assays to assess engineered nanoparticle toxicity in a human cell line. Toxicol Appl Pharmacol. 2009;234:222-35.

113. Fröhlich E, Meindl C, Pieber T. Important issues in the cytotoxicity screening of nano-sized materials. EURO-NanoTox Lett. 2010;1:1-6.

114. Damoiseaux R, George S, Li M, Pokhrel S, Ji Z, France B, et al. No time to lose-high throughput screening to assess nanomaterial safety. Nanoscale. 2011:3:1345-60.

115. Hillegass JM, Shukla A, Lathrop SA, MacPherson MB, Fukagawa NK, Mossman BT. Assessing nanotoxicity in cells in vitro. Wiley Interdiscip Rev Nanomed Nanobiotechnol. 2010;2:219-31.

116. Anguissola S, Garry D, Salvati A, O'Brien PJ, Dawson KA. High content analysis provides mechanistic insights on the pathways of toxicity induced by amine-modified polystyrene nanoparticles. PLOS ONE. 2014;9:e108025.

117. George S, Pokhrel S, Xia T, Gilbert B, Ji Z, Schowalter M, et al. Use of a rapid cytotoxicity screening approach to engineer a safer zinc oxide nanoparticle through iron doping. ACS Nano. 2010;4:15-29.

118. Jan E, Byrne SJ, Cuddihy M, Davies AM, Volkov Y, Gun'ko YK, et al. Highcontent screening as a universal tool for fingerprinting of cytotoxicity of nanoparticles. ACS Nano. 2008;2:928-38.

119. Joris F, Valdeperez D, Pelaz B, Soenen SJ, Manshian BB, Parak WJ, et al. The impact of species and cell type on the nanosafety profile of iron oxide nanoparticles in neural cells. J Nanobiotechnol. 2016;14:69.

120. Harris G, Palosaari T, Magdolenova Z, Mennecozzi M, Gineste JM, Saavedra $\mathrm{L}$, et al. Iron oxide nanoparticle toxicity testing using high-throughput analysis and high-content imaging. Nanotoxicology. 2015;9(Suppl 1):87-94.

121. Fröhlich E, Samberger C, Kueznik T, Absenger M, Roblegg E, Zimmer A, et al. Cytotoxicity of nanoparticles independent from oxidative stress. J Toxicol Sci. 2009;34:363-75.

122. Ma J, Lu X, Huang Y. Genomic analysis of cytotoxicity response to nanosilver in human dermal fibroblasts. J Biomed Nanotechnol. 2011;7:263-75.

123. van der Zande M, Undas AK, Kramer E, Monopoli MP, Peters RJ, Garry D, et al. Different responses of Caco-2 and MCF-7 cells to silver nanoparticles are based on highly similar mechanisms of action. Nanotoxicology. 2016;10:1431-41.

124. Sahu SC, Zheng J, Yourick JJ, Sprando RL, Gao X. Toxicogenomic responses of human liver HepG2 cells to silver nanoparticles. J Appl Toxicol. 2015;35:1160-8.

125. Xu L, Taro T, Xu M, Hanagata N. Toxicity of silver nanoparticles as assessed by global gene expression analysis. Mater Express. 2011;1:74-9.

126. Bouwmeester H, Poortman J, Peters RJ, Wijma E, Kramer E, Makama $\mathrm{S}$, et al. Characterization of translocation of silver nanoparticles and effects on whole-genome gene expression using an in vitro intestinal epithelium coculture model. ACS Nano. 2011:5:4091-103.

127. Bajak E, Fabbri M, Ponti J, Gioria S, Ojea-Jimenez I, Collotta A, et al. Changes in Caco-2 cells transcriptome profiles upon exposure to gold nanoparticles. Toxicol Lett. 2015;233:187-99. 
128. Li JJ, Kawazoe N, Chen G. Gold nanoparticles with different charge and moiety induce differential cell response on mesenchymal stem cell osteogenesis. Biomaterials. 2015;54:226-36.

129. Fisichella M, Berenguer F, Steinmetz G, Auffan M, Rose J, Prat O. Toxicity evaluation of manufactured $\mathrm{CeO} 2$ nanoparticles before and after alteration: combined physicochemical and whole-genome expression analysis in Caco-2 cells. BMC Genomics. 2014;15:700.

130. Hanagata N, Zhuang F, Connolly S, Li J, Ogawa N, Xu M. Molecular responses of human lung epithelial cells to the toxicity of copper oxide nanoparticles inferred from whole genome expression analysis. ACS Nano. 2011;5:9326-38.

131. Mahmoudi M, Laurent S, Shokrgozar MA, Hosseinkhani M. Toxicity evaluations of superparamagnetic iron oxide nanoparticles: cell "vision" versus physicochemical properties of nanoparticles. ACS Nano. 2011;5:7263-76

132. Liu Y, Zou J, Wang X, Wang T, Wang J. Effects of 2,3-dimercaptosuccinic acid-coated $\mathrm{Fe}_{3} \mathrm{O}_{4}$ nanoparticles on genes in two mouse cell lines. $J$ Biomed Nanotechnol. 2014;10:1574-87.

133. Fede C, Millino C, Pacchioni B, Celegato B, Compagnin C, Martini P, et al. Altered gene transcription in human cells treated with Ludox(R) silica nanoparticles. Int J Environ Res Public Health. 2014;11:8867-90.

134. Hanagata N, Xu M, Takemura T, Zhuang F. Cellular response to ZnO nanoparticle toxicity inferred from global gene expression profiles. Nano Biomed. 2010;2:153-69.

135. Osmond-McLeod MJ, Osmond RI, Oytam Y, McCall MJ, Feltis B, Mackay$\operatorname{Sim} \mathrm{A}$, et al. Surface coatings of $\mathrm{ZnO}$ nanoparticles mitigate differentially a host of transcriptional, protein and signalling responses in primary human olfactory cells. Part Fibre Toxicol. 2013;10:54.

136. Osmond-McLeod M, Oytam Y, Osmond R, Sobhanmanesh F, McCall $M$. Surface coatings protect against the in vitro toxicity of zinc oxide nanoparticles in human hepatic stellate cells. Nanomed Nanotechnol. 2014;5:232.

137. Eom HJ, Chatterjee N, Lee J, Choi J. Integrated mRNA and micro RNA profiling reveals epigenetic mechanism of differential sensitivity of Jurkat T cells to AgNPs and Ag ions. Toxicol Lett. 2014:229:311-8.

138. Sun B, Liu R, Ye N, Xiao ZD. Comprehensive evaluation of microRNA expression profiling reveals the neural signaling specific cytotoxicity of superparamagnetic iron oxide nanoparticles (SPIONs) through N-methyl-D-aspartate receptor. PLoS ONE. 2015;10:e0121671.

139. Nymark $P$, Wijshoff $P$, Cavill $R$, van Herwijnen $M$, Coonen ML, Claessen S, et al. Extensive temporal transcriptome and microRNA analyses identify molecular mechanisms underlying mitochondrial dysfunction induced by multi-walled carbon nanotubes in human lung cells. Nanotoxicology. 2015;9:624-35.

140. QuY, Huang Y, Lu X. Proteomic analysis of molecular biocompatibility of gold nanoparticles to human dermal fibroblasts-fetal. J Biomed Nanotechnol. 2013;9:40-52.

141. Li JJ, Lo SL, Ng CT, Gurung RL, Hartono D, Hande MP, et al. Genomic instability of gold nanoparticle treated human lung fibroblast cells. Biomaterials. 2011;32:5515-23.

142. Lin YR, Kuo CJ, Lin HY, Wu CJ, Liang SS. A proteomics analysis to evaluate cytotoxicity in NRK-52E cells caused by unmodified nano-Fe(3)O(4). ScientificWorldJournal. 2014;2014:754721.

143. Witzmann FA, Monteiro-Riviere NA. Multi-walled carbon nanotube exposure alters protein expression in human keratinocytes. Nanomedicine. 2006;2:158-68

144. Haniu H, Matsuda Y, Takeuchi K, Kim YA, Hayashi T, Endo M. Proteomicsbased safety evaluation of multi-walled carbon nanotubes. Toxicol Appl Pharmacol. 2010;242:256-62.

145. Yuan J, Gao H, Sui J, Chen WN, Ching CB. Cytotoxicity of single-walled carbon nanotubes on human hepatoma HepG2 cells: an iTRAQ-coupled 2D LC-MS/MS proteome analysis. Toxicol In Vitro. 2011;25:1820-7.

146. Ge Y, Bruno M, Wallace K, Winnik W, Prasad RY. Proteome profiling reveals potential toxicity and detoxification pathways following exposure of BEAS-2B cells to engineered nanoparticle titanium dioxide. Proteomics. 2011;11:2406-22.

147. Sund J, Palomaki J, Ahonen N, Savolainen K, Alenius H, Puustinen A. Phagocytosis of nano-sized titanium dioxide triggers changes in protein acetylation. J Proteom. 2014;108:469-83.
148. Armand L, Biola-Clier M, Bobyk L, Collin-Faure V, Diemer H, Strub JM, et al. Molecular responses of alveolar epithelial A549 cells to chronic exposure to titanium dioxide nanoparticles: a proteomic view. J Proteom. 2016;134:163-73.

149. Pan CH, Liu WT, Bien MY, Lin IC, Hsiao TC, Ma CM, et al. Effects of size and surface of zinc oxide and aluminum-doped zinc oxide nanoparticles on cell viability inferred by proteomic analyses. Int J Nanomed. 2014;9:3631-43.

150. Carrola J, Bastos V, Jarak I, Oliveira-Silva R, Malheiro E, Daniel-da-Silva $\mathrm{AL}$, et al. Metabolomics of silver nanoparticles toxicity in $\mathrm{HaCaT}$ cells: structure-activity relationships and role of ionic silver and oxidative stress. Nanotoxicology. 2016;10:1105-17.

151. Li X, Zhang C, Zhang X, Wang S, Meng Q, Wu S, et al. An acetyl-L-carnitine switch on mitochondrial dysfunction and rescue in the metabolomics study on aluminum oxide nanoparticles. Part Fibre Toxicol. 2016;13:4.

152. Bo Y, Jin C, Liu Y, Yu W, Kang H. Metabolomic analysis on the toxicological effects of TiO(2) nanoparticles in mouse fibroblast cells: from the perspective of perturbations in amino acid metabolism. Toxicol Mech Methods. 2014:24:461-9.

153. Jin C, Liu Y, Sun L, Chen T, Zhang Y, Zhao A, et al. Metabolic profiling reveals disorder of carbohydrate metabolism in mouse fibroblast cells induced by titanium dioxide nanoparticles. J Appl Toxicol. 2013;33:1442-50.

154. Dong MS, Choi JY, Sung JH, Kim JS, Song KS, Ryu HR, et al. Gene expression profiling of kidneys from Sprague-Dawley rats following 12-week inhalation exposure to silver nanoparticles. Toxicol Mech Methods. 2013;23:437-48.

155. Cho WS, Kim S, Han BS, Son WC, Jeong J. Comparison of gene expression profiles in mice liver following intravenous injection of 4 and $100 \mathrm{~nm}$-sized PEG-coated gold nanoparticles. Toxicol Lett. 2009;191:96-102.

156. Fujita K, Morimoto Y, Ogami A, Myojyo T, Tanaka I, Shimada M, et al. Gene expression profiles in rat lung after inhalation exposure to C60 fullerene particles. Toxicology. 2009;258:47-55.

157. Coccini T, Fabbri M, Roda E, Sacco M, Manzo L, Gribaldo L. Gene expression analysis in rat lungs after intratracheal exposure to nanoparticles doped with cadmium. J Phys Conf Ser. 2011;304:012025.

158. Halappanavar S, Saber AT, Decan N, Jensen KA, Wu D, Jacobsen NR, et al. Transcriptional profiling identifies physicochemical properties of nanomaterials that are determinants of the in vivo pulmonary response. Environ Mol Mutagen. 2015:56:245-64.

159. Jeon Y, Park S, Kim W, Ham J, Lee M. The effects of $\mathrm{TiO}_{2}$ nanoparticles on the protein expression in mouse lung. Mol Cell Toxicol. 2011;7:283.

160. Jeon Y, Park S, Lee M. Proteomic analysis of hepatotoxicity induced by titanium nanoparticles in mouse liver. J Korean Soc Appl Biol Chem. 2011;54:852.

161. Jeon Y, Park S, Lee M. Toxicoproteomic identification of $\mathrm{TiO}_{2}$ nanoparticle-induced protein expression changes in mouse brain. Anim Cells Syst. 2011;15:107-14.

162. Jeon Y, Park S, Rhee S, Lee M. Proteomic profiling of the differentially expressed proteins by $\mathrm{TiO}_{2}$ nanoparticles in mouse kidney. Mol Cell Toxicol. 2010:6:414

163. Gao Y, Gopee NV, Howard PC, Yu LR. Proteomic analysis of early response lymph node proteins in mice treated with titanium dioxide nanoparticles. J Proteom. 2011;74:2745-59.

164. Juang YM, Lai BH, Chien HJ, Ho M, Cheng TJ, Lai CC. Changes in protein expression in rat bronchoalveolar lavage fluid after exposure to zinc oxide nanoparticles: an iTRAQ proteomic approach. Rapid Commun Mass Spectrom. 2014;28:974-80.

165. Li J, Zhao Z, Feng J, Gao J, Chen Z. Understanding the metabolic fate and assessing the biosafety of $\mathrm{MnO}$ nanoparticles by metabonomic analysis. Nanotechnology. 2013;24:455102.

166. Lee SH, Wang TY, Hong JH, Cheng TJ, Lin CY. NMR-based metabolomics to determine acute inhalation effects of nano- and fine-sized $\mathrm{ZnO}$ particles in the rat lung. Nanotoxicology. 2016;10:924-34. 